\title{
REFLECTIONS ON THE EU FOREIGN POLICY OBJECTIVES BEHIND THE 'INTEGRATED APPROACH' IN THE RESPONSE TO PIRACY OFF SOMALIA
}

\begin{abstract}
Maria Luisa Sanchez Barrueco*
Summary: The upsurge in pirate attacks on European vessels in the Gulf of Aden during 2008 brought the forgotten conflict of Somalia back onto the international political agenda. It soon became clear that no initiative off the Somali coast could be effective unless it was accompanied by efforts to relieve the root causes of piracy. This article examines first the essential features of the situation in Somalia, providing the necessary background to fully grasp not only the root causes of piracy, but also the risk to Western security posed by recent developments in this failed State. As regards the European Union, piracy-related incidents in the Gulf of Aden entail multi-faceted threats against European interests. A key question which arises is the extent to which the European response to Somali pirates truly follows a comprehensive, integrated approach. Following an empirical analysis of development co-operation tools implemented in Somalia over recent years, as well as a thorough assessment of the legal mandate and several shortcomings faced by the first EU naval military operation, EU NAVFOR-Atalanta, we conclude that the EU response to piracy is stretched and inadequate both on land and off-shore. Therefore, the reality contradicts to a great extent political statements at the EU level. A possible explanation for this somewhat frustrating outcome is provided by a theoretical examination of the objectives (besides having an impact on the ground in Somalia) behind EU Foreign Policy. Objectives linked to the visibility of the EU as a global actor, as well as the Europeanisation of foreign and internal policies of Member States will be particularly emphasised.
\end{abstract}

\section{The root causes of piracy off the Somali coast - the call for an integrated approach both on land and off-shore}

Somalia was ranked first in the Failed States Index in 2008. ${ }^{1}$ This dubious distinction gives the misleading impression that the borders of

\footnotetext{
" Maria Luisa Sanchez Barrueco, Professor and Researcher, Institute for European Studies, University of Deusto, Spain.

1 'The Failed States Index 2008' Foreign Policy (2008) July/August, <http://www.foreignpolicy.com/story/cms.php?story_id=4350\&page $=1>$. All internet references were last accessed 12 June 2009.
} 
Djibouti, Kenya and Ethiopia, together with the Indian Ocean, demarcate a state in the Horn of Africa. However, this land has actually been home to several powers since enemy clans ousted Siad Barre's dictatorial regime in 1991, a year marking the beginning of the country's descent into political turmoil and anarchy.

The official government of Somalia, usually known as the Transitional Federal Government (TFG), was formed in late 2004 after a twoyear peace process supported by Kenya and the US. The international community recognised the TFG and actively backed it with financial aid aimed at improving governance and relieving the conditions of the population. Nevertheless, the TFG has proven unable to act as an effective central government, since vast areas of the country are not under its control. A large northern region (Somaliland) soon declared its independence in 1991 and has remained stable ever since, despite not being officially recognised by foreign governments. Puntland has also been a self-governing region since 1998. It does not aim at independence, but has its own king and local institutions. The southern part of the country is shared out between Islamic militias and local warlords.

In June 2006, a coalition of clerics, business leaders, and Islamic court militias known as the Islamic Courts' Union (ICU) defeated powerful Mogadishu warlords gathered together as part of the Alliance for the Restoration of Peace and Counter-Terrorism and took control of the capital. Mogadishu was won back with the help of Ethiopian troops, backed by the United States, six months later. However, Islamic militias have continued to struggle for power with the TFG, local clans and foreign troops.

Somalia provides yet another example of the blowback effect of foreign military intervention in failed States. On the insistence of the United Nations (UN), and ultimately of the US, concerned at the prospect of Somalia becoming another piece in the 'War on Terrorism' puzzle, Ethiopia agreed in early 2006 to send troops to its neighbour and traditional enemy. The main goal was to win back the capital city Mogadishu and reinforce the TFG against the Islamist threat in the south. But a wave of support for Islamic militias spread through the country as the occupying forces moved forward. Ideology was apparently not the underlying driving force. According to analysts, ${ }^{2}$ the population simply wanted a return to normal civilian life, and Sharia law was a cheap price to pay for law and order, something that foreign troops could not offer. In the end, two years of solving its neighbour's problems was a far too heavy burden for

2 B Jopson, 'Which enemy is greater: Islamists or hijackers?' Financial Times (Washington 25 November 2008) <http://us.ft.com/ftgateway/superpage.ft?news_id=ftol 12420082049 034221\&page $=2>$. 
Ethiopia to bear alone, and it thus welcomed the UN-sponsored Djibouti Peace Agreement calling for its withdrawal as of June $2008 .^{3}$ The operation started in November and saw the abandonment of Ugandan and $\mathrm{Bu}-$ rundian AMISOM soldiers ${ }^{4}$ to their fate.

The Djibouti peace process may be seen as the starting point of a gradual, albeit significant, shift in the international community perspective on Somalia. Support had traditionally been given to clan leaders. The Chair of the TFG, Abdullahi Yusuf, was in fact originally from the Puntland governing clan. However, the TFG had proven unable to succeed in stabilising the country over the years ${ }^{5}$ and its weakness helped the spread of radical Islamism. A new path seen as the best way to stabilise Somalia was to endorse moderate Islamists, and representatives of the Alliance for the Re-liberation of Somalia (ARS) were recognised as valid partners for negotiations in Djibouti. The TFG was further weakened for two reasons. First, without the support of Ethiopian forces, Islamic militias gradually regained control over swaths of Somalia. Second, in-fighting between the president and two successive prime ministers finally resulted in the resignation of President Yusuf on 29 December 2008. A moderate Islamist, Sheikh Sharif Ahmed, was elected on 2 February 2009 as Somalia's new president. His election caused initial scepticism because he had chaired the Islamic Courts' Union government in 2006 and had also taken part in the Djibouti peace process as the leader of the moderate faction of the

\footnotetext{
3 The Djibouti Peace Agreement was signed on 9 June 2008 between the TFG and the Alliance for the Re-liberation of Somalia (ARS) in the presence of a number of observer States (France, UK, US, Saudi Arabia and Djibouti) and groups (African Union, European Union, League of Arab States, and the Organization of Islamic Conferences). The agreement provided several important points: first, a ceasefire between TFG and ARS forces for an initial period of 90 days, which would be renewable; second, a request to the UN for the deployment of an international stabilisation force from countries friendly to Somalia but excluding neighbouring States (thus not naming traditional enemies such as Ethiopia or Eritrea); third, the formal dissociation of the ARS from any armed groups or individuals not adhering to the peace process; fourth, an engagement to ensure unhindered humanitarian access to affected populations; and fifth, the establishment of a Joint Security Committee to follow up the implementation of security agreements. The full text of the agreement is available at <http://www.hiiraan.com/news2/2008/Jun/agreement_between_transitional_federal_ governament_and_the_allaince_for_re_liberation_of_somalia.aspx $>$.

4 AMISOM (numbering less than 3,0000 Ugandan and Burundian troops) is a regional peacekeeping mission operated by the African Union with the approval of the United Nations [UNSC Res 1772 (20 August 2007)]. It started in January 2008 and had been renewed six-monthly until June 2009. Its mandate covers support to the TFG, implementation of a national security plan, training Somali security forces, and assistance in creating a secure environment for the delivery of humanitarian aid. Since the Ethiopian troops' withdrawal made AMISOM the main target of attacks, panic-driven indiscriminate reactions have increasingly attracted grievous accusations of human rights violations <http://www.hrw. $\mathrm{org} / \mathrm{en} /$ news/2009/02/05/somalia-new-violence-highlights-need-independent-inquiry>.

5 See European Parliament, Resolution on the situation in the Horn of Africa, 15 January 2009, doc. P6_TA(2009)0026 point H.
} 
ARS opposing the TFG. On the one hand, there were certain fears about supporting a politician with such a close association with the Al-Qaeda faction in Somalia, ${ }^{6}$ whilst on the other, the perception was that he was the last chance to form a national unity government in Somalia. ${ }^{7}$

Despite Western support, President Sharif's internal position as of June 2009 is paradoxically weaker than that of the erstwhile UIC government. His resolution introducing Sharia law, though not interpreting it strictly, was passed by the Somali Parliament in April, which gave him some room to manoeuvre and be accepted by both local Islamists and the international community. Additionally, he also succeeded in convincing the UN-sponsored International Conference in support of the Somali Security Institutions (Brussels, 22-23 April 2009) to commit USD 213 million to improving Somalia's security sector. ${ }^{8}$ Nevertheless, the hardline wing of the ARS, known as Al-Shabaab ('Youth'), which did not accept the terms of the Djibouti peace agreement, have gradually taken over the southern part of the country, with the alleged connivance of AlGaeda leaders in the city of Kismayo as well as Eritrean volunteers. These radical Islamists have declared war on both the TFG of President Sharif and Ahlu Sunna Waljamaca, an umbrella group of traditionally peaceful Sunni sects who do not share the strict Saudi Arabian-inspired Wahhabi interpretation of Islam. ${ }^{9}$

${ }_{6}$ Suffice it to mention that two of his closest allies in 2004 were Aden Hashi Farah 'Eyrow', the alleged leader of Al-Qaeda in Somalia, who was assassinated in an US selective attack on 1 May 2008, and Hassan Dahir Aweys, a hard-line leader of the Al-Shabaab militia, who has been on the US list of terrorists since November 2001, even if they split paths after the Djibouti peace process.

7 '... we must acknowledge that although President Sharif used to be a part of the Islamic Courts, he is now leading a broad-based transitional unity government, he is trying to implement the Djibouti Peace Agreement. He is trying to prevent the exploitation of youth and the abuse of Islam.' David Miliband (British Foreign Secretary), 'Our shared future: building coalitions and winning consent', Speech at the Oxford Centre for Islamic Studies, 21 May 2009 <http://www.fco.gov.uk/en/newsroom/latest-news/?view=Speech\&id=18130489>.

'...for over a year, we had been seeking to persuade our Western partners that Sheikh Sharif was the only leader capable of rallying a consensus to support him.' Bernard Kouchner (French Foreign Minister), 'Piraterie: pourquoi la France aide la Somalie', Le Figaro (Paris, 22 April 2009), English translation at <http://www.franceonu.org/spip.php?article3818>.

'The TFG of Somalia has courageously committed itself to leading a broad-based political process ... through peaceful means. ... I reiterate all my solidarity and firm support to the government of Somalia'. Javier Solana (EU High Representative for the CFSP), 'Statement reiterating solidarity and support for the transitional government of Somalia' (12 May 2009) S/123/09 <http://www.consilium.europa.eu/uedocs/cms_data/docs/pressdata/EN/declarations/107655.pdf>.

8 See Final Communiqué at <http://www.consilium.europa.eu/uedocs/cms_data/docs/ pressdata/en/misc/107357.pdf>.

9 Al-Shabaab's techniques actually seek to terrorise the population in areas under its control (ML Sanchez Barrueco, Interview with Somali novelist Mohamed Khalif Jama, 26 April 2009). This includes the stoning to death of a 13 year-old rape victim ('Stoning victim begged 
In short, Somalia has moved fast towards a civil war on religious grounds, a fact that makes the assessments provided just a year ago no longer valid. At the beginning of 2008, the EC Delegation in Nairobi described the conflict as distinct, stating that Somalia, unlike other States suffering internal wars in the $21^{\text {st }}$ century, was not torn by language, religion, ethnicity or culture, but mostly by clan affiliation.

The Somali people have not historically espoused a governance system predicated on a nation-state. Rather, the pre-eminent focus of the social, legal, political and economic organization of the Somali nation has been and remains the clan. ... The four major Somali clan families, each comprising well over a million members, are the Darod, the Hawiye, the Dir and the Digil-Mirifle. It is the power and resource-sharing relationships between these xolos and among their sub-clans that primarily determine the viability of governance systems in Somalia. ${ }^{10}$

Although clans remain the primary feature of social organisation in Somalia, their political power has strongly diminished since Islamists began to regain influence at the end of 2008. The reform of the national Parliament provides a good example of this shift. Traditionally, the 275 seats were equally divided among the four major clans, and a smaller amount of representation was awarded to a coalition of minor clans. In December 2008, however, the size of the Parliament was doubled to include 200 representatives of the ARS and 75 representatives of civil society and the diaspora. The religious division between radical and moderate Muslims is therefore rather recent and it would not be an exaggeration to say that it sprang up in reaction to foreign military occupation and is being encouraged by the foreign press, probably to justify further intervention.

While the political mayhem remains, Somalia keeps sinking into an almost irreparable humanitarian crisis. ${ }^{11}$ The civil war has killed thou-

for mercy', BBC News, 4 November 2008 <http://news.bbc.co.uk/2/hi/africa/7708169. stm>), teenage suicide bombers ('Rebels claim Somali suicide bomb', BBC News, 25 May 2009 <http://news.bbc.co.uk/2/hi/africa/8066807.stm>), desecration of Sunni graves ('Somali rage at grave desecration', BBC News, 8 June $2009<$ http://news.bbc.co.uk/2/ hi/africa/8077725.stm>) and targeted assassination of Somali journalists ('Fifth Somali journalist killed this year', Garowe Online (Somalia 8 June 2009) <http://www.garoweonline.com/artman2/publish/Press_Releases_32/Fifth_Somali_journalist_killed_this_year. shtml>).

10 EC Delegation in Nairobi, 'The role of the Somali clan system' Annex no 10 to European Commission Joint Strategy Paper for Somalia 2008-2013 <http://ec.europa.eu/development/icenter/repository/scanned_so_csp10_en.pdf> 99.

11 According to information managed by the EC delegation in Nairobi, Somalia's health indicators are some of the worst in Africa. Estimated life expectancy at birth is low, while average life expectancy is 47 . Infant mortality is 115 deaths per 1,000 births. Infectious diseases, nutritional deficiencies and birth-related problems are major health risks, and water 
sands of civilians, the number of internally displaced persons is around 1.2 million people, and the remaining population teeters on the edge of famine in what has been repeatedly termed a 'forgotten conflict'. ${ }^{12}$ Ironically, it is not the massive humanitarian disaster on land but the situation off-shore which has succeeded in putting Somalia back onto the international agenda.

The Somali coastline is 3,900 kilometres long and has one of the highest concentrations of fish in the world's oceans. Somali fisheries were once relatively profitable but suffered a sharp decline at the turn of the millennium for three main reasons. Firstly, the civil war destroyed the inland transport and refrigeration facilities essential for fish processing, with the result that this incipient industry simply ceased to exist. Secondly, no Somali government has been able to deter illegal fishing in its territorial waters, and foreign ships have plundered halieutic resources, often using practices that show little consideration for fish stocks or local fishermen. ${ }^{13}$ Last but not least, many unscrupulous European vessels saw the fragility of the TFG as an opportunity to dump toxic, even nuclear, waste in Somali waters. ${ }^{14}$ The subsequent impoverishment of the population in coastal cities has been repeatedly invoked to legitimise the rise of piracy, but the assumption that pirates are former Somali fishermen has not been proven, at least not to a significant extent. There seems to be a closer relationship with northern Somali clans connected with second-level officials within the Puntland administration.

Nevertheless, the upsurge in pirate-related attacks in the Indian Ocean in recent years, particularly since $2008,{ }^{15}$ has turned the Somali

borne diseases are on the increase. HIV/AIDS prevalence is estimated at less than $1 \%(2001)$. Primary school enrolment is only $20.8 \%$ for boys and $16.9 \%$ for girls. The overall adult literacy rate is $25 \%$ for males and $12 \%$ for females. Literacy in rural areas is extremely low.

12 NGOs still present in Somalia helplessly try to put the Somali humanitarian disaster back onto the international agenda. See Human Rights Watch $(<\mathrm{http}$ ://www.hrw.org/africa/somalia>) and Médecins Sans Frontières, 'Reaching out. MSF in Somalia' (13 August 2007) <http://www.msf.org/source/countries/africa/somalia/2007/reaching_out_report. pdf $>$.

13 Local fishermen complained in 2006 that foreign fishing boats did not have a licence and used illegal fishing methods. Some of them would even allegedly hire Somali militias to drive away the local fishermen. H Knaup, 'The poor fishermen of Somalia' Der Spiegel (12 April 2008) <http://www.spiegel.de/international/world/0,1518,594457,00.html>.

14 The Indian Ocean tsunami in December 2004 unearthed dozens of containers of toxic waste and deposited them along the Somali coast. In 2006, a team of specialists sent to the region to investigate discovered nine toxic waste sites along 700 kilometres of coastline in southern Somalia, Knaup (n 13). The UN envoy to Somalia said in June 2008 that 'Somalia has become a dumping ground for solid waste, chemical waste and probably nuclear waste', A Ould-Abdallah, 'The crisis in Somalia' (transcript) Chatham House (London 19 June 2008) <http://www.chathamhouse.org.uk/files/11931_190608ouldabdallah.pdf>.

15 According to the International Maritime Bureau (IMO), the number of incidents of piracy or armed robbery at sea against ships experienced an unprecedented $11 \%$ worldwide in- 
coast into some of the most dangerous waters in the world, forcing the international community, especially the world's trading powers, to focus again on Somalia. The Gulf of Aden is a natural waterway linking the Indian Ocean with the Mediterranean. Rampant piracy in the region thus hampers industrial and consumer goods from reaching the European market via the traditional sea route.

Confronting the piracy scourge off Somalia's coast needs an integrated approach that encompasses short-term security or defence policy tools with long-term tools aimed at addressing lawlessness and impoverishment in Somalia itself. Such statements have often been heard among scholars as well as in the media. Nonetheless, the expression 'integrated approach' takes on a new meaning when used in connection with the European Union due to the fact that piracy off the Somali coast has become a multilevel and cross-pillar concern, as the following discussion will show.

Let us begin with integrated policies. The waters around the Horn of Africa are crucial to European economies. More than 16,000 vessels pass through the Gulf of Aden each year and the risk raised by piracy is so severe that some important shipping companies have already decided to take the longer and more expensive sea route around the Cape of Good Hope off southern Africa. ${ }^{16}$ The negative impact on international trade is worsened by the soaring marine insurance premiums faced by ship-owners, which have grown tenfold in some cases. Energy supplies are another victim of pirate attacks, since $12 \%$ of the world's traded oil passes through these waters.

The situation is also a harsh one for European fishermen, an economic sector already affected by rises in oil prices and diminishing halieutic resources. The tuna season off the Somali coast represents around $35 \%$ of the yearly turnover for fishermen. According to estimates, decreases in catches in 2008 caused a loss of over EUR 65m to the 43 EC

crease, but a $200 \%$ one in comparison to 2007 in the critical trade corridor linking the Suez Canal and the Indian Ocean. IMO, Annual Piracy Report 2008 (2009) Doc. MSC.4/Circ. 133 (19 March 2009) <www.imo.org>. In March 2009, 6 vessels were hijacked and there were another 29 failed attempts. This trend increased in April, with 17 hijackings and 26 failed attempts.

16 Most shipping companies are reluctant to publicise having been the subject of a pirate attack for fear of a bad impact on their image. This applies especially to robberies because any booty barely reaches the daily cost of chartering the vessel, J Henley, 'All at sea' Guardian (19 November 2008). Nevertheless, the high cost of the Suez Canal and the upsurge in piracy leading to soaring insurance costs have already pushed several of the most important maritime operators to divert their ships towards the Cape of Good Hope, particularly east-bound, when ships travel empty ( $R$ Wright, 'Lines put new faith in Hope' Financial Times (26 May 2009). The AP Møller-Maersk group (Europe's biggest ship-owner, with 83 tankers), Svitzer (towage and salvage operator, a member of the latter) and Odfjell (the Norwegian owner of 90 chemical tankers) have decided on this already, Financial Times (22 November 2008). 
fishing boats operating in the zone in $2008 .{ }^{17}$ Shipping companies and fishermen are fully covered by insurance, and therefore insurance companies have urged European governments to find an effective solution.

The final link in the chain of those affected by piracy are European consumers, since the additional costs of diverting routes, complementary coverage, and even ransoms are generally passed on and find their way into the prices that we pay for our goods.

Pirate attacks entail a serious environmental risk as well. Such a threat often remains unsaid, but is increasingly likely, given the fact that targeted vessels are mostly oil or chemical tankers, and that pirates are using ever more powerful weaponry. A major environmental disaster in the Gulf of Aden could be triggered if a tanker were set on fire or even sunk, a probability which grows day by day.

Finally, there is an effect on Development Policy, since the insecurity of the country both on land and off-shore makes it extremely difficult to deliver humanitarian aid. The MSF Co-ordinator in Somalia put it clearly as follows:

... all humanitarian aid activity implies an unsaid contract in which we support a suffering population and, in exchange, this population protects us and respects us. Now this contract has smashed into smithereens ...[because of] a small but violent minority, ... [and i]t will never be the same.$^{18}$

However, all experts seem to agree that initiatives off-shore will only be a band-aid until the root cause - widespread lawlessness in Somalia - is addressed on-shore. The platitude 'find stability on land first, then order will return to the seas' can only be achieved by means of development aid.

As can be seen, piracy off the Somali coast has had a direct impact on different EU policies of what will be the first pillar until the Lisbon Treaty comes into force (notably, commercial, fisheries and development policies), calling for a reaction from their external wings. It also affects indirectly other integrated domains, such as the internal market, development and environmental policy.

The third pillar - Justice and Home Affairs - is also concerned by piracy. Pirates deliberately target European individuals and companies abroad, casting doubt on the ability of European diplomacy to protect

17 Carmen Llorente, 'Seguros a precio de oro contra los piratas de Somalia' El Mundo (Madrid 1 December 2008).

18 Statement by Javier Fernández (MSF Co-ordinator in Somalia), El Mundo (Madrid 7 February 2008) <http://www.elmundo.es/elmundo/2008/02/07/cronicasdesdeafrica/1202377064.html>. 
the integrity of their citizens in third countries. On land, aid workers ${ }^{19}$ and journalists ${ }^{20}$ are either kidnapped by ransom-seeking thugs or killed. Off-shore, 2008 was a fateful year regarding the hijacking of vessels, and many Europeans were taken hostage. This strategy proved very lucrative for pirates, since the only solution to major kidnappings and vessel seizures before the launching of the EU naval operation in December 2008 was the payment of multi-million dollar ransoms by European governments and ship-owners. ${ }^{21}$

But the main European initiative to tackle piracy in the Indian Ocean has been taken within the framework of the second pillar, the Common Foreign and Security Policy (CFSP), or more precisely the European Security and Defence Policy (ESDP), as the issue is perceived to be a security problem and therefore has escaped the ordinary realm of politics. Let us examine the array of threats to European security posed by Somali pirates.

European States are supposed to guarantee, even by force, the security of supply of goods and oil en route to European countries. However, pirate attacks have undermined western governments' authority time and again, despite military efforts to stop them. Piracy in the Indian Ocean provides a good example of the post-Cold War concept of 'asymmetric warfare': a conventional military fighting mostly non-State actors, with the military capability of the two sides being very unequal, and yet the more powerful belligerent remains profoundly vulnerable and unable to annihilate its smaller enemy, which is either dispersed on land (or sea) or it is easily mistaken for the civilians that widely support it, or it has nothing to lose in suicide or pirate attacks.

Pirates have become increasingly audacious since the beginning of 2008. Although they do not sail under the Jolly Roger any longer, ships transporting weapons, luxury yachts or even foreign warships have not daunted them. Moreover, pirates generally receive real or tacit support

19 In December 2007, two MSF staff, both of whom were Spanish, were kidnapped in Bossaso in a week. In January 2008, three MSF staff, one of them French, were murdered in Kismayo (south Somalia). In July 2008, the UNDP representative in Somalia, Osman Ali Ahmed, was shot dead in Mogadishu. In January 2009, three MSF aid workers were abducted over a ten-day period in the central region.

20 Two journalists from The Daily Telegraph (Briton Colin Freeman and Spaniard José Cendón) were released on 4 January 2009, after 40 days of captivity and the reported payment of a ransom. Somali journalists are not so lucky, they simply get killed most times. According to Amnesty International, at least 10 Somali journalists have been killed in the last two years.

21 A few years ago, ransoms were hundreds of thousands of dollars. In 2008, however, the highest ransom ever, reportedly USD $3.2 \mathrm{~m}$, was paid for the Saudi supertanker Syrius Star months after its hijacking on 15 November 2008. Over USD 30m was paid in ransoms in 2008. 
from the rest of the community, not just because they often present themselves as champions of Somali interests against the foreign invader. ${ }^{22}$ In fact, ransoms paid to pirates have, to a large extent, ended up in coastal cities, flourishing Eyl or Bosaso among them, leading to a positive net result on land: everyone benefits from the incoming cash, even regional leaders, apparently. ${ }^{23}$

In addition, the military expansion of the Islamic Courts throughout the southern part of Somalia has raised security concerns among the western allies because of the alleged links between some of their factions and the Al-Qaeda East Africa network. A link between Somali pirates and Islamism has been suggested, but as mentioned before, piracy appears to have a closer relationship with certain Somaliland or Puntland clans than with Al-Qaeda, as the Al-Shabaab radical Islamic militia's reaction to the seizure of the Arabian supertanker, Sirius Star, seems to prove.

As we have seen so far, piracy is definitely a cross-pillar subject affecting integrated fisheries and internal market EC policies as well as the home affairs and security pillars. Now the time has come to assess whether the various European initiatives addressing piracy off the Somali coast truly follow an integrated approach or whether they show signs of inconsistencies between the three remaining EU pillars.

\section{Inconsistencies and limitations of the European response to piracy off the Somali coast}

The ability to successfully put forward a comprehensive approach represents the difference between conventional power and structural power in foreign policy. The post-Cold War context undermined the structures which supported the East-West order, and therefore States felt the need to strengthen their military capabilities to survive in an increasingly dangerous world. At the same time, the breakdown of the old structures demanded a reorganisation of foreign policy according to non-conventional (structural) standards so that vulnerability could be diminished and foreign policy actors (States or international organisations) could influence long-term developments. In order to understand the following analysis, it is useful to recall the definition of 'structural foreign policy' and 'conventional foreign policy' according to Keukeleire and MacNaughtan:

\footnotetext{
22 Javier Espinosa, interview with Farah Ismail (pirate) El Mundo (Madrid 23 January 2009) <http://www.elmundo.es/elmundo/2008/12/15/internacional/1229315057.html>; Xan Rice, interview with Asad Abdulahi (pirate) Guardian (22 November 2008) <http://www. guardian.co.uk/world/2008/nov/22/piracy-somalia>.

23 'Piracy brings rich booty to Somali shores' Financial Times (3 March 2009) <http://www. ft.com/cms/s/0/680c8924-0792-11de-9294-000077b07658.html>.
} 
Conventional foreign policy is orientated towards states, military security, crises and conflicts ... Structural foreign policy refers to a foreign policy which, conducted over the long-term, seeks to influence or shape sustainable political, legal, socio-economic, security and mental structures. ${ }^{24}$

The expression 'comprehensive approach' regarding peace-building made its way into Community jargon following the Balkan experience. This concept aims to address all aspects of structural instability in countries at risk in order to promote an environment leading to peace. A comprehensive approach assumes that conflicts cannot be overcome by diplomatic or military means alone. However, this perspective requires an enormous amount of financial resources and it is very time-consuming, because all EU actors involved must prioritise the objective of conflict prevention in their policy towards the target country and thus accept concessions in terms of other policy objectives (eg commercial policy). This scale of involvement can only be afforded for a limited number of countries in the closest strategic circle of the EU (currently only the Balkans). ${ }^{25}$ As far as other regions are concerned, insufficient EU implementation leads to scattered resources and therefore undermine EU credibility in the region. This might apply, as will be discussed next, to EC involvement in Somalia.

\subsection{Elements of a European structural foreign policy in Somalia}

a) Scarce and scattered long-term development tools

Development policy tools are primarily aimed at fostering sustainable conditions in the recipient country as declared in Article 177.1 of the EC Treaty. By virtue of its position as the biggest provider of development aid in the world, the EU (EC and Member States (MS)) is theoretically able to use development co-operation to trigger changes in third countries in line with specific foreign policy objectives (good governance and democracy, respect for human rights, and conflict prevention, among others). But some analysts have suggested that the EU relies too much on the positive spill-over of programmes fostering co-operation, democracy or economic assistance, without sufficiently considering the actual impact of each initiative. In fact, democracy programmes can unleash extreme nationalism when newborn parties are based upon ethnic or religious divisions, whereas development and trade concessions can exacerbate inequalities among different identity groups. ${ }^{26}$

${ }_{24}$ S Keukeleire and J MacNaughtan, The Foreign Policy of the European Union (Palgrave Macmillan, Basingstoke 2008) 25-6.

25 Keukeleire and MacNaughtan (n 24) 218-9.

${ }^{26} \mathrm{KE}$ Smith, European Union Foreign Policy in a Changing World ( $2^{\text {nd }}$ edn Polity Press, Cambridge 2008) 165. 
In addition, the European Commission, which is in charge of managing development co-operation, highlighted in 2007 the need to count on rapid and flexible instruments when dealing with fragile situations and recommended 'a mapping of bilateral and EU aid modalities under the different pillars' with a particular emphasis on the 'complementarity between crisis management related instruments such as CFSP/ESDP joint actions, the Instrument for Stability, the African Peace Facility and long term cooperation instruments'. ${ }^{27}$

When it comes to Somalia, the European Commission manages development co-operation through DG Development, inserting Somalia into the ACP group even if this country is not a signatory to the ACP-EC Partnership Agreement. The Commission manages most of the expenditure of the EDF, despite it being financed through national contributions, therefore escaping the general framework of the general budget of the European Union. Within the Commission, most EDF programmes are managed by the EuropeAid Co-operation Office, but a small proportion related to humanitarian aid is managed by DG-ECHO (0.8\% of total 2007 payments). The Commission has repeatedly pointed out the high risks associated with management of the $\mathrm{EDF}^{28}$ but they do not apply to Somalia, given the special features of this country, as will be shown next. As far as management is concerned, EDF resources are usually mobilised in two stages: first, the Commission takes the financing decision upon the request of the ACP State; second, a National Authorising Officer concludes contracts and authorises payments which are in turn executed and audited by the Commission. The structural weaknesses inherent in governance regarding partner countries might entail waste of EU money. In the case of Somalia, however, the long-lasting power vacuum has led to the exclusion of all Somali authorities from the tasks assigned to the National Authorising Officer within the framework of the EDF. Instead, the Head of the EC delegation in Nairobi carries them out, supposedly acting on behalf of the Somali people.

The strategic framework for the co-operation of the European Commission with Somalia under the $10^{\text {th }}$ EDF is reflected in the Joint Strategy Paper for Somalia 2008-2013. ${ }^{29}$ The Commission takes as its starting point the Millennium Development Goals (MDGs) and has produced an ambitious planning work that goes from cluster reports on different ar-

27 European Commission, Communication 'Towards an EU response to situations of fragility - engaging in difficult environments for sustainable development, stability and peace' COM (2007) 643, 25 October 2007, 12.

28 European Court of Auditors, 2007 Annual Report on the activities funded by the $7^{\text {th }}, 8^{\text {th }}$ and $9^{\text {th }}$ EDFs [2008], OJ C286/02/273.

29 Joint Strategy Paper (n 10). 
eas, ${ }^{30}$ to identifying three pillars ${ }^{31}$ for future action, and strategic objectives and focal sectors. However, the likelihood of these words having an actual impact on the ground is difficult to assess.

In fact, a total amount of EUR $215.8 \mathrm{~m}$ has been allocated through the EDF to Somalia during the 2008-2013 period, the biggest share of which (EUR 212m) is 'to cover macroeconomic support, sectoral policies, programmes and projects' by means of the Somalia Special Support Programme. The remainder (EUR $3.8 \mathrm{~m}$ ) is intended to cover unforeseen needs, such as emergency response.

The EDF, which is primarily aimed at pursuing development objectives, has interestingly evolved to cover security concerns as well, since it is financing four African Union peace-keeping operations (AMISOM among them) through the African Peace Facility financial instrument. As of 2007, in addition to a EUR 250m general financial envelope, EUR $15 \mathrm{~m}$ has been provided to the peace support operation to cover the operational costs of the AMISOM headquarters in Mogadishu and the provision of troops.

Food aid represents the bulk of EC aid to Somalia. Apart from the amounts already mentioned, Somalia has benefited from the Food Security Thematic Programme with an initial allocation of EUR $12 \mathrm{~m}$ for the period 2007-2010. This facility is managed by EuropeAid and therefore subject to call-for-tender procedures. In addition, Somalia has received EUR $27 \mathrm{~m}$ as part of the food aid budgetary line in 2008, which is managed by ECHO. ${ }^{32}$ Unlike EuropeAid, this office is merely a donor and does not implement projects, but just finances them. Funds are channelled to the population through civil partners that have subscribed to a partnership agreement with the Commission (NGOs, UN agencies and international organisations) and then make specific requests in the event of an emergency situation.

The high level of insecurity and risk in Somalia makes it extremely difficult to live up to expectations regarding development co-operation in

30 First, governance, security and the rule of law; second, a macroeconomic policy framework and data development; third, infrastructure; fourth, social services and protection of vulnerable groups; fifth, productive sectors and the environment; and sixth, livelihoods and solutions for the displaced.

31 Roughly speaking, the first is related to peace, security and good governance, covering disarmament, demobilisation and reintegration, the establishment and strengthening of core public and private sector institutions, decentralisation, and conflict resolution mechanisms. The second pillar focuses on investing in people and covers social services and protection of vulnerable groups. The third pillar aims to establish a sustainable enabling environment for rapid poverty-reducing development, to expand employment and reduce poverty. Joint Strategy Paper (n 10) 25-33.

32 European Commission, press release 'European Commission provides $€ 15$ million for emergency food aid in the Horn of Africa', IP/08/1527, 16 October 2008. 
most fields. To take as an example the goal of building an embryo of civil society, the Commission assumes that Somali non-State actors are not in a position to fulfil the eligibility criteria to act directly as applicants or as partner organisations. Therefore, support to non-State actors in Somalia is paradoxically implemented by funding other countries' non-State actors, ${ }^{33}$ even though all actions should be carried out in close co-operation with a Somali counterpart. The same applies to actions against antipersonnel landmines, financed under the long-term component of the Instrument for Stability, where no initiative has been taken since 2005. ${ }^{34}$

Another development co-operation tool that does not seem to adapt well to Somalia's situation is the European Instrument for Democracy and Human Rights (EIDHR). Its main asset is its flexibility, which permits it to bypass partner governments and directly interact with non-State actors. However, the limited scope of projects makes the EU look more interested in enhancing its visibility on the ground than in fostering true change in the target country. The investment of the EIDHR in Somalia fits this impression of scarce and scattered aid which is always granted to European actors ${ }^{35}$ that do not seem to have close links with the Somali diaspora.

To sum up, EC development tools in Somalia depend primarily on short-term tools such as food aid that are intended to alleviate the situation of extreme hunger and drought but do not provide the conditions required for long-term development. Long-term development tools appear to be scarce and scattered. In addition, the building of civil society is officially marginalised by default in EC development co-operation in Somalia. Projects implemented by the European Commission do not thus benefit from the traditional advantages of community participation, ${ }^{36}$ namely

33 European Commission, Guidelines for grant applicants, Open call for proposals 2008, EUROPEAID/128091/L/ACT/SO.

34 European Commission, Action against antipersonnel landmines in Somalia, closed 18 July 2005, EuropeAid/121327/C/G/SO.

35 Over the 2000-2006 period, there were only six projects financed by the EIDHR in Somalia: setting aside a EUR $1 \mathrm{~m}$ grant to an Italian NGO working for the eradication of Female Genital Mutilation (2006-2009) and a EUR 1.158m grant to a Swedish Christian NGO to foster democracy and reconciliation over a 2-year period; other allocations were smaller and aimed at promoting the protection of children against violence (a EUR 846,000 grant to a Finnish NGO covering Somalia and three other countries over a 3-year period), supporting human rights and peace organisations (a EUR 331,000 grant to a Dutch NGO over 19 months), empowering civil society through demobilisation and reintegration (a EUR 11,594 grant to a UK consultant), and enhancing gender considerations (a EUR 550,000 grant to a Swiss NGO over one year). EuropeAid, EIDHR 2000-2006, <http://ec.europa.eu/europeaid/where/worldwide/eidhr/documents/updated_report_by_location_en.pdf>.

36 World Bank, The World Bank Participation Sourcebook, <http://www.worldbank.org/ wbi/sourcebook/sbpdf.htm>; FAO, 'Participation: our vision' <http://www.fao.org/participation/ourvision.html>. 
better consideration of the specific local features, a better cost-benefit relation, and sustainability of their positive impact in the long run.

b) A new legal framework to combat illegal fishing

There are other European initiatives that might have an impact on the root causes of piracy in the long run. The new regime against illegal fishing, adopted in September 2008 within the framework of the Fisheries Policy, is noteworthy in this respect.

Illegal fishing or, to be more precise, illegal, unreported and unregulated (IUU) fishing covers fishing without licences and all fishing activities that infringe on national, regional or international regulations and conventions. Even though initiatives in this regard do not specifically concern the Gulf of Aden, the Commission has acknowledged that IUU activities are easier when coastal states lack the resources to properly control their territorial waters, a typical feature of Somalia.

The Commission states that IUU fishing is not only a major threat to the sustainability of fish stocks and marine biodiversity, but also a distorting factor regarding competition among EU fishermen, leading to lower market prices, loss of market share and a threat to the viability of EC companies. ${ }^{37}$ However, it must be acknowledged that, in line with the globalisation of the economy, the use of flags of convenience by European ship-owners has risen with a view to reducing costs in registration fees, labour conditions and taxes. Third countries tolerating flags of convenience benefit in turn from tax revenues and the possible creation of jobs. These States (mostly developing countries) lack the means to carry out effective control measures, or the will to do so, if the resources concerned are not theirs.

Accusations of IUU fishing have often been levelled at European vessels operating in the Gulf of Aden and off the south-eastern coast of Somalia but, given the strict rules regulating fishing in EU countries, the process is more complex. It usually takes place in two stages. First, a ship flying a flag of convenience of a third country that tolerates IUU fishing, but which is owned by a European company, catches fishery products that can be considered as IUU but which are not Community goods yet. In the subsequent stage, IUU catches are transhipped to an EC vessel of the same European company, becoming then regular Community fishery products, ready to enter the EU for distribution. A thorough control of transhipments (either in port or in territorial waters) and landing, as well as traceability of fishery products is thus essential to deter such 'pirate fishermen' from operating.

37 <http://ec.europa.eu/fisheries/cfp/external_relations/illegal_fishing/q_a_en.htm>. 
In September 2007, the Commission put forward a proposal ${ }^{38}$ with a view to closing the doors of the EU to illegal fishery products and vessels. The Council adopted Regulation 1005/2008 on 29 September $2008^{39}$ following a consultation procedure. This is to enter into force on 1 January 2010. The new Community rules governing access to Community ports for fishing vessels flying the flag of a third country have been further strengthened to ensure stringent control of the legality of fishery products landed by such fishing vessels. The basic principle is the prohibition of importing fishery products obtained from IUU fishing into the Community. ${ }^{40}$ To ensure its effectiveness, full traceability of all fishery products traded with the Community is sought. Access to Community ports is denied in principle to third-country fishing vessels unless they provide accurate information on the legality of their catches by means of a "catch certificate' validated by the flag State and ensuring that 'catches have been made in accordance with applicable laws, regulations and international conservation and management measures'. ${ }^{41}$

In addition, Regulation 1005/2008 sets strict rules with a view to preventing irregular transhipments between third-country vessels and EC vessels. These can only take place in ports, with transfers in Community waters being explicitly prohibited. ${ }^{42}$ Moreover, the Commission is entrusted with the responsibility of establishing a Community IUU vessel list. This blacklist shall include EC and third-country fishing vessels involved in IUU fishing whose flag States have not complied with official requests addressed by the Commission to take all necessary measures against them. Regarding flag States, the Council, acting by a qualified majority on a proposal from the Commission, will establish a list of nonco-operating States ${ }^{43}$ against whom a set of counter-measures is listed in Article $38 .{ }^{44}$ Finally, a stricter scheme of inspections is envisaged in

38 European Commission, Proposal for a Council regulation establishing a Community system to prevent, deter and eliminate illegal, unreported and unregulated fishing, COM (2007) 602 final, 17 October 2007.

39 Council Regulation (EC) 1005/2008 establishing a Community system to prevent, deter and eliminate illegal, unreported and unregulated fishing (2008) OJ L286/1.

40 Council Regulation (EC) 1005/2008 (n 39) art 12.1.

41 Council Regulation (EC) 1005/2008 (n 39) art 12.3.

42 Council Regulation (EC) 1005/2008 (n 39) art 4.3.

43 Council Regulation (EC) 1005/2008 (n 39) art 33.1.

44 The range of measures includes prohibition of importation into the EC of fishery products caught under the flag of such states (catch certificates issued by national authorities will no longer be accepted), prohibition of purchase of their vessels by EC operators, prohibition of reflagging of EC vessels to such countries, prohibition of concluding chartering agreements with MS, prohibition of exportation of EC fishing vessels to those countries, prohibition of joint fishing operations, denunciation of any standing bilateral fisheries agreements, and blocking of negotiations for bilateral fisheries agreements or partnership agreements with the EC. 
Article 9, whereby 'Member States shall carry out inspections in their designated ports of at least 5\% of landing and transhipment operations by third country fishing vessels each year'. However, suspected vessels ${ }^{45}$ shall be subject to verifications in all cases.

Nevertheless, the effectiveness of the new regime applicable to IUU fishing will largely depend, on the one hand, on the implementation rules (yet to be adopted by the Commission as of July 2009), and on the other, on the commitment of those MS benefiting indirectly from IUU practices to put an end to such practices.

A major EU contribution to the security of fish supplies in coastal communities, as well as a deterrent to European vessels illegally fishing off the Somali coast, would be the negotiation and signature of a Fisheries Partnership Agreement with Somalia. But the Commission does not deem it feasible, given the various shortcomings faced by the TFG in terms of stability and administrative capacity. ${ }^{46}$

\subsection{Conventional foreign policy against piracy: the 'modest although realistic' EU NAVFOR-Somalia}

\section{An overview of ESDP missions}

The EU's inability to react promptly and suitably to the Kosovo crisis raised a wave of frustration in most European capitals that in 1999 brought about the necessary agreement to launch an ESDP that would pursue objectives related to peace-keeping, humanitarian relief and rescue operations, common known as Petersberg missions.

The impact of the ESDP on the nature of the EU as a global actor has been discussed thoroughly and we will not dwell on it here. Suffice it to say that 'military' scholars tend to stress the increased co-operation in the fields of capabilities, interoperability and deployability to assert that the EU is moving "from a predominantly "civilian" CFSP to a much more muscular and "harder" common defence policy', ${ }^{47}$ whereas 'civilian' scholars usually highlight the fact that military instruments serve goals

45 Article 9.2 lists as suspected vessels those engaged in activities that may be considered as IUU fishing and that are sighted by a competent authority of a Member State, vessels reported in the framework of a notification made under the Community alert system against IUU fishing, vessels presumed by the Commission to have engaged in IUU fishing, and fishing vessels appearing on an IUU vessel list adopted by a regional fisheries management organisation.

$46 \mathrm{~J}$ Borg (Commissioner for Fisheries and Maritime Affairs) 'Combating Piracy: Strength in Unity', Speech at the Seminar on piracy and armed robbery against shipping, Brussels, 21 January 2009, SPEECH/09/14.

47 J Howorth, 'From Security to Defence: the Evolution of the CFSP' in C Hill and M Smith (eds), International Relations and the European Union (OUP, Oxford 2005) 179. 
that on the whole remain civilian. ${ }^{48}$ Similarly, the nature of most ESDP operations to date has been solely civilian. ${ }^{49}$ The truth is, as Keukeleire points out, that the ESDP quantitatively changed the nature of CFSP from a declaratory foreign policy focused on diplomacy to a more actionorientated [one] ... [a]nd although still limited in scope, the EU finally ha[s] boots on the ground. ${ }^{50}$

The fundamental basis for ESDP missions can be found in the CFSP objectives, as stated in Article 11 TEU, which cover the safeguarding of the common values, fundamental interests, independence and integrity of the EU in accordance with the UN Charter; the strengthening of the security of the EU; the preservation of peace and the strengthening of international security; the promotion of international co-operation; and the development and consolidation of democracy and the rule of law, as well as respect for human rights and fundamental freedoms.

Article 17 TEU makes a sole reference to ESDP missions, though rather implicitly, when stating that '[q]uestions referred to in this Article shall include humanitarian and rescue tasks, peacekeeping tasks and tasks of combat forces in crisis management, including peacemaking.' Apart from the general scope of these operations, no further specific question (eg decision-making or financing) is dealt with in the Treaty and the answer must be found in general CFSP provisions applying to joint actions (the legal instrument used to regulate ESDP missions), bearing in mind that a number of restrictions will apply to possible military aspects of the operation.

The process of launching an ESDP mission is complex and involves many actors both at the European and national level. Co-ordination with third States or other international organisations is vital. As far as decision-making is concerned, ${ }^{51}$ the origin of an ESDP mission is an early warning triggered either by the Policy Unit and the Situation Centre in Brussels or by national FP ministries through their Permanent representations. A number of Council working groups will then be asked for advice by the Political and Security Committee (PSC), the Committee on Civilian Aspects of Crisis Management (CIVCOM), the Politico-Military

\footnotetext{
48 KE Smith, EU Foreign Policy in a Changing World (Polity Press, Cambridge 2008) 72-3.

49 While 12 ESDP missions have been of a civilian nature, only 5 ESDP missions have been strictly military operations: Concordia (Macedonia), Althea (Bosnia and Herzegovina), Artemis (Congo), EUFOR-Congo and EUFOR-Chad ('Aperçu des missions et opérations de l'Union européenne en juin 2008' (2008) ESDP Newsletter (6) $30<$ www.consilium.europa. eu/esdp>). EU NAVFOR Somalia can now be added to this list.

50 Keukeleire and MacNaughtan (n 24) 57.

51 The following considerations are largely based on the decision-making process as described by H Hazelzet, 'Human Rights Aspects of EU Crisis Management Operations: from Nuisance to Necessity’ (2006) 13 International Peacekeeping 565.
} 
Group (PMG), and advisors on the financial aspects of CFSP. The Council Secretariat carries out the planning tasks while ensuring co-ordination between civilian and military operational instruments and structures. At the same time, MS internally assess their possible contribution to the operation, be it through expertise, military facilities, personnel, equipment or financial means. In addition, complementary measures will possibly be adopted by the Commission through financial tools in the framework of EC development policy. A fact-finding mission may also be sent to report on the situation on the ground.

On the basis of the different reports gathered, the PSC may recommend to the Council the launching of an ESDP mission. Should this occur, a Joint Action is prepared for adoption by the Council to regulate the legal aspects of the operation. A parallel operational plan details the respective tasks and obligations of all the subjects involved. In the case of a military operation, the rules of engagement are also specified. MS start sending national contingents to the theatre of operations and, within five days of the Council decision, the EU can be present on the ground. ${ }^{52}$

As regards the financing of ESDP missions, Article 28 TEU sets some basic rules: expenditure will be charged to the general EC budget by default, apart from two cases (paragraph 3): 'operating expenditure arising from operations having military or defence implications' and 'cases where the Council acting unanimously decides otherwise.' Practical implementation of this general principle with regard to ESDP missions has led to a differentiation between two situations.

On the one hand, purely civilian crisis-management operations are funded from the CFSP budgetary line of the EC general budget (Chapter 19 03), and therefore follow the budgetary procedure laid down in Article 272 of the EC Treaty. The significant role played by the European Parliament in this procedure, as well as the European Court of Auditors' competences as regards budgetary management control should never be neglected. Budgetary implementation is in the hands of the Commission, in line with Article 274 of the EC Treaty, and the CFSP budget is no exception. When a Joint Action is adopted, the Commission commits, contracts and disburses the budget allocated to the ESDP mission. This procedure has applied to the majority of operations so far, as well as to the civilian aspects of missions with military implications.

On the other hand, purely military operations are financed through a special mechanism named Athena, established by the Council in 2004. Athena was set up to administer the financing of common costs of operations having military or defence implications. Athena is endowed with

52 Hazelzet (n 51) 566. 
legal capacity and has a permanent structure. A Special Committee is tasked with the management of common costs from the preparatory phase to the termination of each military operation. The Council Decision establishing Athena ${ }^{53}$ embraced a rather restrictive interpretation of the common costs to be financed under this scheme. Consequently, the ratio of costs financed in common to total incremental costs for an operation is small (less than 10\%). The remaining expenditure is financed directly by MS on the basis of the 'costs lie where they fall' principle. ${ }^{54}$

It might happen, though, that both procedures intertwine in a specific operation for the sake of efficiency. For instance, in 2005, 6 MS voluntarily financed, through Athena, specific common costs over the first two months of the EUSEC-Congo operation until the CFSP budgetary allocations were made available.

The first ESDP operation was the EU Police Mission in Bosnia and Herzegovina, which ran from January 2003 to December 2006, although the first purely military operation was Operation Concordia in Macedonia, which started in March 2003. Since then, more than 20 missions have been launched on three continents (Europe, Africa and Asia). In spite of the varying and evolving nature and scope of ESDP missions, there are three elements upon which MS seem to agree: first, ESDP missions display a collective character, leading to the implicit rejection of unilateral interventions; second, the cover of the UNSC is deemed essential for the legitimacy of the mission not to be contested; and third, the existence of limits regarding the humanitarian mission's goals and their implementation. ${ }^{55}$

\section{The legal basis and scope of EU NAVFOR-Somalia}

The legal basis for European military intervention off the coast of Somalia was provided at the international level mainly by two Resolutions of the UNSC. The first was Resolution 1816 (2008), ${ }^{56}$ which authorised, for a period of six months starting on 2 June, States co-operating with the TFG to enter the territorial waters of Somalia in order to repress acts of piracy and armed robbery at sea.

53 Council Decision 2007/384/CFSP of 14 May 2007 establishing a mechanism to administer the financing of the common costs of European Union operations having military or defence implications (Athena) [2007] OJ L 152/14.

54 Keukeleire and MacNaughtan (n 24) 115-6.

55 C Diaz Barrado, 'Las denominadas "intervenciones de humanidad Č y la Unión Europea', in A Del Valle (ed), Los nuevos escenarios internacionales y europeos del Derecho de la seguridad (Escuela Diplomática/AEPDIRI/BOE, Madrid 2003) 145.

56 UNSC Res 1816 (2 June 2008) UN Doc S/RES/1816. 
The SC acted under Chapter VII of the Charter of the United Nations, the aim of which is to authorise the use of armed force to bring to an end threats to international peace, breaches of peace or acts of aggression. Resorting to this dynamic on the part of non-State actors has become a consolidated practice in the decade since UNSC Resolution 1333 (2000) took financial action against the Taliban and included Al-Qaeda as a terrorist organisation. However, its application to piracy proves the seriousness attached to pirate attacks in the Horn of Africa. In addition, as Pozo points out, ${ }^{57}$ recourse to Chapter VII has also been common in justifying humanitarian intervention in failed States since UNSC Resolution 794 (1992) on Somalia.

UNSC Resolution 1816 established two conditions for naval military intervention in the territorial waters of Somalia: one formal, that the TFG would provide advance notification to the UN Secretary-General; and one substantial, that means used in the fight against pirates should be consistent with relevant international law.

UNSC Resolution $1838^{58}$ went a major step further in early October by inviting '...States interested in the security of maritime activities to take part actively in the fight against piracy on the high seas off the coast of Somalia, in particular by deploying naval vessels and military aircraft, in accordance with international law' (particularly, the UN Convention on the Law of the Sea of 10 December 1982, UNCLOS). It also recommended that States issue vessels with 'advice and guidance on appropriate precautionary measures to protect themselves from attack or actions to take' in the event of a pirate attack, an addition that raised concerns among the maritime community about the ability of States to provide effective protection against pirates. Following Resolution 1838, the Council of the EU decided to officially launch the first ever European naval mission.

The UNSC warmly welcomed this initiative in December by means of Resolution $1846^{59}$ and substantially toughened its tone regarding the fight against piracy:

9. [The UNSC c]alls upon States and regional organizations that have the capacity to do so, to take part actively in the fight against piracy ... by deploying naval vessels and military aircraft, and through seizure and disposition of boats, vessels, arms and other related equipment used in the commission of piracy and armed robbery off the coast of Somalia ...

57 P Pozo Serrano, 'Estados fallidos, derecho internacional humanitario y seguridad internacional' in C Ramón Chornet (ed), Los retos humanitarios del siglo XXI (Tirant lo Blanch, Valencia 2004) 181.

58 UNSC Res 1838 (7 October 2008) UN Doc S/RES/1838.

59 UNSC Res 1846 (2 December 2008) UN Doc S/RES/1846. 
and authorised, for an initial period of 12 months, the use of force against pirates within the territorial waters of Somalia.

10. [The UNSC d]ecides that for a period of 12 months from the date of this resolution States and regional organizations cooperating with the TFG in the fight against piracy and armed robbery at sea off the coast of Somalia, for which advance notification has been provided by the TFG to the Secretary-General, may:

(a) Enter into the territorial waters of Somalia for the purpose of repressing acts of piracy and armed robbery at sea, in a manner consistent with [action permitted by UNCLOS for the repression of piracy on the high seas]

(b) Use, within the territorial waters of Somalia, in a manner consistent with [action permitted by UNCLOS for the repression of piracy on the high seas], all necessary means to repress acts of piracy and armed robbery at sea;

In doing so, the UNSC temporarily established a specific derogation from UNCLOS, whose definition of piracy omits attacks committed in the territorial waters of a State. According to Article 101 UNCLOS:

Piracy consists of any of the following acts:

(a) any illegal acts of violence or detention, or any act of depredation, committed for private ends by the crew or the passengers of a private ship or a private aircraft, and directed:

1. on the high seas, against another ship or aircraft, or against persons or property on board such ship or aircraft,

2. against a ship, aircraft, persons or property in a place outside the jurisdiction of any State.

(b) any act of voluntary participation in the operation of a ship or of an aircraft with knowledge of facts making it a pirate ship or aircraft;

(c) any act of inciting or of intentionally facilitating an act described in subparagraph (a) or (b).

To understand the serious concerns invoked by certain European States, this provision must be linked to Article 106 regulating liability for seizure without adequate grounds and establishing that:

Where the seizure of a ship or aircraft on suspicion of piracy has been effected without adequate grounds, the State making the seizure shall be liable to the State the nationality of which is possessed by the ship or aircraft for any loss or damage caused by the seizure. 
Although the questions raised by the prosecution of arrested pirates will be dealt with in the next section, mention should be made of UNSC Resolution 1851 of 16 December $2008 .{ }^{60}$ The UNSC invited all States and regional organisations involved

... to conclude special agreements or arrangements with countries willing to take custody of pirates in order to embark law enforcement officials ("shipriders") from the latter countries, in particular countries in the region, to facilitate the investigation and prosecution of persons detained as a result of operations conducted under this resolution for acts of piracy and armed robbery at sea off the coast of Somalia, provided that the advance consent of the TFG is obtained for the exercise of third state jurisdiction by shipriders in Somali territorial waters ...

Regarding the European legal basis for military intervention, the Council first created a co-ordination cell in Brussels (EU NAVCO) on 19 September as the first step towards the first European maritime intervention, code-named EU NAVFOR-Atalanta. EU-NAVCO comprised 4 officials, entrusted with the task of co-ordinating the EU military in order 'to support the activities of MS deploying military assets in theatre'. ${ }^{61}$ MS were invited to "provide the EU Coordination Cell with any relevant information on their operational activities in theatre and on the current situation in the area, including exchanges of information with merchant vessels'. ${ }^{62}$ The Head of EU NAVCO was tasked with co-ordination at the operational level with the relevant departments of the UN-Secretariat, the WFP and the International Maritime Organisation (IMO). ${ }^{63}$ Political co-ordination with other international actors was ensured by the Secretary General/High Representative (SG/HR) Javier Solana, who acts as the primary point of contact with the UN and the African Union (AU). The Head of EU NAVCO was politically accountable to the Political and Security Committee (PSC) of the Council. The EU Military Committee (EUMC) was asked to monitor the military aspects of co-ordination. ${ }^{64} \mathrm{EU}$ NAVCO was closed once EU NAVFOR-Atalanta was fully operative.

On 11 November 2008, the Council of the European Union officially launched Operation Atalanta by means of Joint Action 2008/851/CFSP 65

\footnotetext{
60 UNSC Res 1851 (16 December 2008) UN Doc S/RES/1851.

61 Council Joint Action 2008/749/CFSP of 19 September 2008 on the European Union military coordination action in support of UNSC Res 1816 (2008) (EU NAVCO) [2008] OJ L $252 / 39$ art 2.

62 Council Joint Action 2008/749/CFSP (n 61) art 8.2.

63 Council Joint Action 2008/749/CFSP (n 61) art 9.

64 Council Joint Action 2008/749/CFSP (n 61) art 7.

65 Council Joint Action 2008/851/CFSP of 10 November 2008 on a European Union mili-
} 
(JA). According to Article $1 \mathrm{JA}$, the mandate of the mission is to contribute to the protection of vessels cruising off the Somali coast. Vessels of the World Food Programme (WPF) delivering food aid to displaced persons in Somalia are mentioned in first place, in line with UNSC Resolution 1814 (2008), and then, at least formally, other vulnerable vessels, irrespective of their nationality.

The mandate of the operation is detailed in Article 2 JA. Depending on availabilities, EU-NAVFOR is entitled to:

(a) protect vessels chartered by the WFP, particularly when sailing in Somali territorial waters. This protection can include presence on board such vessels;

(b) protect merchant vessels in the areas where it is deployed, based on a case-by-case evaluation of needs;

(c) keep watch over areas off the Somali coast, including Somalia's territorial waters, in which there are dangers to maritime activities, in particular to maritime traffic;

(d) take necessary measures, including the use of force, to deter, prevent and intervene in order to bring to an end acts of piracy and armed robbery which may be committed in the areas where it is present;

(e) arrest, detain and transfer piracy suspects, and seize the vessels of pirates, as well as goods on board;

(f) liaise with other actors working in the region to combat acts of piracy off the Somali coast. Specific mention is made of co-operation with the 'Combined Task Force 150' maritime force which operates within the framework of 'Operation Enduring Freedom'.

Participating MS in EU-NAVFOR to date are the UK, Greece, France, Germany, ${ }^{66}$ Spain, ${ }^{67}$ Italy and Sweden. ${ }^{68}$ Belgium and the Netherlands will join at a later stage. ${ }^{69}$

tary operation to contribute to the deterrence, prevention and repression of acts of piracy and armed robbery off the Somali coasts [2008] OJ L301/33.

66 The German Bundestag (whose support is required to send troops abroad) gave its consent on 19 December 2008. Germany's contribution is the frigate FGS Rheinland Pfalz, which allows a multi-role capability (it includes two helicopters).

67 The Spanish Parliament approved participation in Atalanta on 20 January 2009. Its contribution is the frigate SS Victoria, which has anti-ship missiles and two helicopters. Spain exercises command of the EU mission from April to August 2009 and will then be relieved by a Dutch warship.

68 The Swedish government gave its overwhelming support to Atalanta in February 2009. Three Swedish corvettes joined European forces in the theatre of operations in June 2009.

$69<$ http://consilium.europa.eu/uedocs/cmsUpload/090325FactsheetEUNAVFOR\%20 Somalia-version4_EN.pdf>. 
The Danish case should be carefully looked at. Denmark is faced with a difficult dilemma. On one hand, this MS benefits from an opt-out clause in defence matters, in accordance with Article 6 of the Protocol on the position of Denmark annexed to the TEU. Danish representatives accordingly leave the Council meeting room whenever defence issues are on the agenda, and it is the only MS that does not take part in the European Defence Agency (EDA). ${ }^{70}$ On the other hand, as it is a major seafaring nation, Danish vessels and fishermen have also been the target of pirate attacks in the Gulf of Aden ${ }^{71}$ and the Danish Royal Navy has been patrolling the area since September 2008 within the framework of the NATO effort to stem pirate attacks. As of December 2008, Denmark was leading the naval Combined Task Force-150 as part of the Enduring Peace NATO Operation. Notwithstanding this fact, Denmark does not participate in the EU military response. ${ }^{72}$

In addition, support from third States for EU-NAVFOR is also foreseen in Article 10 JA 2008/749/CFSP, a provision tailored to provide for Norwegian intervention. Being a third State, Norway is currently co-operating with the EU in defence matters and benefits from an Administrative Agreement with the EDA that allows for its participation in joint projects. In contrast with Denmark, the Norwegian government has decided to contribute to Operation Atalanta with a frigate which should join the European force in the area by August $2009 .{ }^{73}$ Switzerland has also expressed an interest in participating. ${ }^{74}$

\section{A not so 'robust mandate': critical shortcomings remain unresolved}

On 17 December 2008, the German Foreign Minister, Frank-Walter Steinmeier, defended the ESDP Atalanta mission before the Bundestag saying that German marine forces would have 'a solid mandate which ...

\footnotetext{
70 ML Sanchez Barrueco, 'L'Agence européenne de défense: un organe intergouvernemental au service d'une institution communautaire?' (2008) Revue du droit de l'Union européenne 529.

${ }^{71}$ The Danish freighter CEC Future and its entire crew were safely released in January 2009 after a ransom was delivered.

72 JA 2008/749/CFSP, preamble, recital 8.

73 Norwegian Ministry of Defence, Press release 5/2009, 27 February 2009, <http://www. regjeringen.no/en/dep/fd/press-centre/Press-releases/2009/norwegian-frigate-to-joineu-navfor-atal.html?id=547266>.

74 According to EU Council press room, 3 March 2009 <http://consilium.europa.eu/showPage.aspx?id=1567\&lang=EN>. Switzerland obviously has no navy, but fearing that EU protection to Swiss vessels would not reach the same level as that ships from the UN or EU receive (30\% of Swiss-bound goods pass through the Gulf of Aden) if only a financial contribution was offered, the Swiss government was discussing in February 2009 whether to send up to 30 elite troops, <http://www.swissinfo.ch/eng/search/Result.html?siteSect $=882 \&$ ty $=$ st $\&$ sid $=10347320>$.
} 
gives [them] the necessary room for manoeuvre against the pirates off the coast of Somalia'. ${ }^{75}$ The German Defence Minister, Franz Josef Jung, did the same thing when sending off the frigate Karlsruhe: the EU naval military mission had an unprecedented 'robust mandate'. Similar statements were carefully leaked to the press and a climate of satisfaction spread as warships participating in the mission joined up in the waters off Somalia.

The initial news was promising indeed. Only a week after the mission started operations, the German frigate taking part in EU-NAVFOR successfully thwarted a pirate attack. ${ }^{7}$ In addition, the Maritime Security Center-Horn of Africa (MSCHOA) was established to provide advice to merchant shipping companies on self-protection measures. ${ }^{77} \mathrm{~A}$ month later, EU NAVFOR presented itself as making 'a real difference in counterpiracy'. ${ }^{78}$

Regarding protection to vessels chartered by the WPF, EU NAVFOR made public statistics according to which 19 vessels had been escorted by March 2009, with the result that more than 121,000 tonnes of food were delivered safely each day to a population amounting to 1.6 million. ${ }^{79}$ As far as protection of merchant shipping is concerned, several successful outcomes have been reported since the first pirate engagement involving a German EU NAVFOR frigate and an Egyptian vessel on 25 December $2008,{ }^{80}$ and hijackings dropped substantially over the first quarter of 2009. In all cases, either the naval operation website itself or the national Ministries of Defence, or both, were quick to applaud with press releases the impressive implementation of the mission by European navies.

75 <http://www.auswaertiges-amt.de/diplo/en/Infoservice/Presse/Reden/2008/081217steinmeier-Atalanta-bundestag.html>.

76 EU-NAVFOR Press release, 25 December 2008, <http://www.consilium.europa.eu/ uedocs/cmsUpload/081226_1st_pirate_engagement.pdf>.

77 The MSCHOA was set by the Council as an element of EU NAVFOR. As a co-ordination centre, MSCHOA aims to picture the situation of vulnerable shipping in the Indian Ocean. In order to do so, its website (<www. mschoa.eu $>$ ) offers, upon secure registration, updated information about vessels and guidance to ship-owners, ships' masters and agents, with a view to reducing the risk of pirate attacks.

78 EU-NAVFOR press release, 30 January 2009 <http://www.consilium.europa.eu/ uedocs/cmsUpload/105728.pdf>.

79 EU NAVFOR Factsheet 04/2009, March 2009 <http://consilium.europa.eu/uedocs/ cmsUpload/090325FactsheetEUNAVFOR\%20Somalia-version4_EN.pdf $>$.

80 The following list is by no means exhaustive: a Spanish EU NAVFOR frigate foiled the hijacking of a UAE merchant ship <http://www.mde.es/NotasPrensa?id nodo $=4072 \&$ accion=1\&id_nota $=1946 \&$ id_vis $=1946>$, a German frigate prevented the hijacking of a besieged German steel cargo vessel on 3 March $2009<\mathrm{http}$ ://www.consilium. europa.eu/uedocs/cms_data/docs/pressdata/en/esdp/106500.pdf>, a French frigate assisted a hundred victims of trafficking in persons who had been held in a supposed pirate mothership on 19 March <http://www.consilium.europa.eu/uedocs/cmsUpload/Floreal. pdf $>$, and a Spanish frigate prevented a Spanish cargo vessel from suffering an attack on 10 April <http://www.mde.es/NotasPrensa?id_nodo=4072\&accion=1\&id_nota=1997>. 
However, life cannot be always a bed of roses in the Indian Ocean. Even the military units of Atalanta have been forced to repel pirate attacks on themselves. ${ }^{81}$ In addition, the end of the winter monsoon in March should discourage the often used statistical analysis of the frequency and scale of pirate attacks. The increase of attacks in April ${ }^{82}$ reinforces the belief that the earlier decline was due to bad weather rather than the presence of European warships.

We consider that several drawbacks undermine EU NAVFOR's capacity to live up to expectations. Given that the scope of protection is limited, with the exception of WFP vessels, Atalanta's mandate is more realistic than robust. Similarly, the boundaries concerning the use of force in the case of engagement with pirates have not been clearly defined and widespread confusion over the prosecution of pirates has given rise to conflict and inconsistencies between certain MS and others. Finally, both the financial envelope and the military assets assigned to Atalanta seem rather limited. All these weaknesses will be assessed next.

\section{a) A realistic mandate given the territorial scope}

Article 2 JA asks EU NAVFOR to provide protection 'to merchant vessels cruising in the areas where it is deployed'. The truth is that the area covered by the mission is far too large to be covered by a few frigates and corvettes. Military authorities have repeatedly stated that guaranteeing protection to every single ship transiting the area is impossible. The biggest catch to date, the Saudi supertanker Sirius Star, was actually seized $800 \mathrm{~km}$ off the Kenyan coast. An awareness campaign was thus carried out among the merchant shipping community, requesting that vessels adopt a responsible attitude and follow instructions given by the MSCHOA.

In addition, the scope of protection extended to merchant vessels is limited because intervention will not be triggered automatically in the event of an attack but will be decided 'on a case-by-case basis'. This criterion might suggest that ships carrying a European flag would prevail but to date this assumption has not proven to be correct. In fact, Atalanta's first pirate engagement took place when a German frigate came to the

81 A German naval tanker taking part in Atalanta was subjected to an attack by a skiff with seven pirates on 29 March 2009 <http://www.consilium.europa.eu/uedocs/cms_data/ docs/pressdata/en/esdp/106976.pdf>. A Spanish frigate helped to detain the skiff afterwards, <http://www.mde.es/NotasPrensa?id_nodo=4072\&accion=1\&id_nota=1986\&id_ vis $=1986>$.

82 Jeffrey Gettleman, 'Somali Pirates seize five ships in 48 Hours' New York Times (6 April 2009) <http://www.nytimes.com/2009/04/07/world/africa/07pirates.html?ref=africa> . 
aid of an Egyptian bulk carrier that was at risk..$^{83}$ 'Case-by-case' engagement means basically that EUNAVFOR forces will intervene solely when the distance to the location of a pirate attack makes intervention possible and effective.

Apart from spontaneous assistance to ships in danger, protection has taken the form of escorts (in the case of WFP vessels) or convoys (in the case of merchant vessels). Atalanta provides naval escorts to all WFP vessels, which usually sail from Mombassa or Tanzania towards Somali ports. Article 2 a) JA permits an armed presence on board these vessels to guarantee protection. Regarding merchant ships, a 'safer transit corridor' was established off the Yemeni coast in the Gulf of Aden, where over 90 percent of pirate attacks occurred in 2007 and 2008. Four points are pinpointed along the corridor and merchant ships registered with the MSCHOA can join the convoy at any one of them in order to successfully reach the Suez Canal.

This scheme omits fishermen. Tuna fishing vessels, in particular, are forced to stay off the southern coast of Somalia, where the bulk of their annual catch is caught from April to November each year. Therefore, the 'safer transit corridor' in the Gulf of Aden is not useful for this economic sector and they remain subject to pirate attacks. On the recommendation of the EU NAVFOR Commander, Atalanta's theatre of operations was extended in May 2009 to respond to increasing pirate threats in the area surrounding the Seychelles archipelago, but the result of this decision has yet to be seen, since it has not been accompanied by the reinforcement of military assets on the ground.

\section{b) The limited capacity to use force against pirates}

The legitimacy of the use of force within the framework of humanitarian intervention is not unanimously accepted at the European level. Whereas some MS, namely France, have displayed a very active position in favour of the right to humanitarian intervention and therefore the legitimacy per se of military operations pursuing the objective of saving human lives, others have not played such a significant role. Consequently, it would seem that a common European position in this respect does not exist, but rather a combination of positions assumed by different MS within the framework of their respective national foreign policies. ${ }^{84}$ This explains, to a certain extent, the ambiguities and doubts that seem to tie the hands of Operation Atalanta when it comes to resorting to force.

\footnotetext{
83 <http://www.mschoa.eu/display.aspx?articlename=27>.

84 Diaz Barrado (n 55) 144.
} 
Article 2 JA states that, faced with a pirate attack, the military personnel involved in the operation can 'take the necessary measures, including the use of force, to deter, prevent and intervene in order to bring to an end acts of piracy and armed robbery'. An accurate interpretation of this provision is essential in understanding EU NAVFOR's scope and, consequently, its limitations. The Joint Action permits a military response as long as it deters, prevents or intervenes to bring to an end a pirate attack. Provided UNCLOS is observed, EU NAVFOR warships can even sink pirate skiffs during an attack. But the JA does not enable EU NAVFOR to bomb, for instance, coastal cities of Somaliland and Puntland where pirates re-supply. However, we should recall that Article 6 of UNSC Resolution 1851 allowed (in December 2008) for intervention 'in Somalia' for the purpose of countering piracy, pursuant to the request of the TFG. A reform of the JA would thus be required, should the need arise to broaden the scope of the European mission.

Likewise, the possibility of resorting to force once an attack is over and the pirates have sailed away is not so clear in the JA. Since pirate attacks happen in an extremely short period of time, a European warship will probably get to the scene when the pirates have already either hijacked the vessel or robbed it and escaped. This situation is unlikely to meet the requirements of an engagement on the grounds of legitimate defence. As a result, fishermen's associations have expressed their concerns about the ability of European forces to deter pirate attacks so long as they have no recourse to more coercive measures. Pirates will thus become more audacious because nobody retaliates. ${ }^{85}$

The former Head of EU NAVCO clearly stated that the decision on a military response after a ship had been seized by pirates could not be taken on the spot by the commanding officer on his own, as higher level co-ordination was required. ${ }^{86}$ As a result, the legal framework makes the situation on the frontline rather confusing. In addition, there are differences in MS legislation with regard to the use of force on international missions. ${ }^{87}$ The EU does not seem interested in handling a pirate crisis in a similar way to the US's determination after the seizure of the Maersk-

85 Europa Press 3 October 2008.

86 Interview with Andrés Breijo (Head of EU NAVCO) El Correo (Bilbao 21 September 2008)

87 In light of the launch of Operation Atalanta, a German law had to be amended. The law prohibited the navy from engaging in policing missions or spontaneous rescue missions. As a result, a German navy frigate spent months sailing off the coast of Somalia while various freighters were being hijacked, and yet the Bundeswehr could not authorise action. Udo Ludwig and Holger Stark, 'German Shipowner Paid Ransom to Somali Pirates' Der Spiegel (16 September 2008) <http://www.spiegel.de/international/world/0,1518,578495,00. html>. 
Alabama in early April 2009, though Middleton suggests that 'customary international law provides basic principles governing the appropriate amount of force to be used where it is lawful to stop and arrest a ship at sea' in Article 101 UNCLOS. ${ }^{88}$

In the event of a pirate attack, gathering enough evidence of the crime has become a precondition for pursuing the pirates. The lack of an effective central government in Somalia which is willing and able to take legal action against European warships does not entitle EU NAVFOR to carry out unlawful searches, arrests or seizures. Hitches following engagements without sufficient evidence have publicly exposed Atalanta's limitations, as will be explained in the following two sections.

\section{c) The arrest of pirates by EU-led forces and the applicability of international humanitarian law and human rights law.}

Beyond the question of whether or not EU-NAVFOR's rules of engagement limit the goal of deterring piracy, the recourse to force by an ESDP mission raises a far-reaching question, that of the liability of European peacekeeping operations under international humanitarian law (IHL) and human rights law.

This matter cannot be tackled without some prior reflections on the Union's international legal personality. International personality enables States or other entities such as international organisations to assume rights and obligations at the international level. Article 281 of the EC Treaty originally conferred legal personality on the European Community but no similar provision was foreseen in the Treaty of Maastricht to cover the activities of the newborn European Union. Articles 1-7 of the Constitutional Treaty corrected this irregular situation and, despite its unfortunate outcome, the same spirit was preserved in Article 47 of the Lisbon Treaty in an equally laconic way ('The Union shall have legal personality'). However, until the Lisbon Treaty comes into force, the EU will not fully enjoy international legal personality.

Notwithstanding this conclusion, scholars essentially agree that the EU benefits from some kind of de facto legal personality enabling it to carry out certain tasks at the international level independently of MS. ${ }^{89}$ Many examples illustrate this. Suffice it to mention that, with respect to ESDP missions, agreements on the status of EU-led armed forces operat-

\footnotetext{
88 R Middleton, 'Briefing Note: Pirates and How to Deal with them' Chatham House (22 April 2009) 3.

89 N Tsagourias, 'The Application of Humanitarian and Human Rights Law to EU Peacekeeping Operations and the Union's International Responsibility' in M Trybus and ND White (eds), European Security Law (OUP, Oxford 2007) 116.
} 
ing as part of a peacekeeping operation are signed by the EU and not by MS sitting in the framework of the Council. ${ }^{90}$

We mentioned before that international legal personality covers the ability to be the subject of rights and obligations. The de facto ability to be the subject of rights is awarded provided that other international actors do not contest the tasks fulfilled by the EU at the international level. However, it is difficult to answer questions concerning the enforcement of the obligations and liability of international organisations following a de facto interpretation. Recognition of the international responsibility of the EU should be explicitly stated in European legal instruments.

There are several indicators pointing to the EU being bound by IHL when launching ESDP missions, even though the EU is not a party to the 1907 Hague Regulations and the Geneva Conventions of 1949. Within the framework of public international law, the fact that armed forces operating in a multinational mission must comply with IHL norms is by no means a new question. It is widely understood that international organisations enjoying a subjective capacity to send troops on the ground in conformity with their constitutional objectives and functions must, accordingly, be bound by the law of armed conflict. ${ }^{91}$ Not specifically targeting the European Union, the Institut de droit international in The Hague stated in 1999 that

every party to an armed conflict in which non-state entities take part, independently of their legal status, as well as the United Nations and the regional organisations and other competent international organisations, must respect international humanitarian law and fundamental human rights. ${ }^{92}$

The IHL rules referred to are those officially recognised as international customary law, as Gasser points out with regard to the UN:

[the UN not being a party to the Geneva Conventions] does not mean ... that troops in a UN-led peace operation are free to behave as they wish. International customary law does apply to the 'United Nations in action', as it does to any other international player. ${ }^{93}$

\footnotetext{
90 Agreement between the European Union and the Republic of Djibouti on the status of the European Union-led forces in the Republic of Djibouti in the framework of the EU military operation Atalanta [2009], OJ L33/43; Agreement between the European Union and the Somali Republic on the status of the European Union-led forces in the Somali Republic in the framework of the EU military operation Atalanta [2009], OJ L10/29.

91 R Kolb, G Porretto and S Vité, L'application du droit international humanitaire et des droits de l'homme aux organisations internationales. Forces de paix et administrations civiles transitoires (Bruylant, Brussels 2005) 127.

92 Institut de droit international, Annuaire, (1999) 68-II art 2.

93 HP Gasser, 'From Military Intervention to Occupation of Territory' in H Fischer, U Froissart, W Heintschel von Heinegg and C Raap (eds), Crisis Management and Humanitarian Protection (Berliner Wissenschafts Verlag, Berlin 2004) 145.
} 
The UN Secretary-General further clarified this issue by means of a Bulletin entitled 'Observance by United Nations forces of international humanitarian law', ${ }^{94}$ which is essentially a codification of the rules and customs deemed applicable to UN-led forces when they are actively engaged in situations of armed conflict as combatants, without prejudice to their responsibility as members of a national armed force bound by the international commitments of the sending State. ${ }^{95}$ These rules entered into force on 12 August 1999.

Similar reflections can be made on EU-led forces. Scholars consider that the EU is bound by the obligation of customary law to respect and ensure respect for humanitarian law by military forces deployed on the ground. At the European level, this can be achieved mainly by means of proper guidance (the adoption of guidelines and instructions), proper supervision of seconded troops and, in the event of an alleged violation of IHL, a prompt reaction to bring it to an end. We agree with Tsagourias on the fact that ' $\mathrm{t}$ ]roop-contributing states have similar obligations and this formula of overlapping obligations ensures respect of humanitarian law'. ${ }^{96}$ However, the need for greater precision concerning respective responsibilities is deemed necessary to ensure adequate and effective criminal prosecution of any breach of IHL that might happen, especially on robust missions. If the Lisbon Treaty eventually enters into force, the legal personality of the EU should make it easier to invoke the international responsibility of the organisation.

Even if IHL rules are theoretically applicable to ESDP operations in one way or another, as has been concluded so far, analysis should be made on a case-by-case basis. As far as EU NAVFOR is concerned, the applicability of IHL to forces operating in the framework of Operation Atalanta is not clear. In the particular case of Somalia, it is worth noting that the situation off-shore does not meet the conditions for it to be considered an armed conflict. Accordingly, arrested pirates may not invoke the status of prisoners of war according to the Third Geneva Convention, ${ }^{97}$ especially because they do not meet the requirements laid down in Article 4A. They are not members of the armed forces of a Party taking part in the conflict or of militias or volunteers corps either. Neither are they members of other organised groups that fulfil certain conditions (particularly the chain of command and the conduct of operations in accordance with the laws and customs of war). A certain parallelism may thus be established between arrested pirates and Al-Gaeda prisoners in

\footnotetext{
94 Bulletin of the Secretary-General, ST/SGB/1999/13.

95 Bulletin of the Secretary-General (n 94) art 1.1.

96 Tsagourias (n 89) 121.

97 Geneva Convention (III) relative to the Treatment of Prisoners of War. 12 August 1949.
} 
Guantanamo. These have not benefited from the status of prisoners of war, unlike Taliban detainees held at the same facility. ${ }^{98}$ Likewise, pirates do not easily fit into either the definition or the intention of civilian populations to be protected against certain consequences of war in the sense of the IV Geneva Convention. ${ }^{99}$

The question of the need to adapt IHL to the armed conflicts of the $21^{\text {st }}$ century, which usually show the features of asymmetric warfare, as mentioned above, falls well beyond the scope of this article. Suffice it to say that the inapplicability of the law of armed conflict (IHL) to the treatment of pirates and their situation as detainees by EU NAVFOR-Somalia does not imply that these persons are completely deprived of their rights. Arrested pirates still benefit from the protection offered by human rights law (HRL), with which European military forces must comply.

The simplest way to justify such a conclusion is to recall that although forces operating in the framework of EU NAVFOR act under the European flag, this can never be a way out of their responsibilities as armed forces of a country signatory to the European Convention on Human Rights (ECHR). All States that are participants in the Atalanta operation, both MS and Norway, are parties to the ECHR, Article 1 of which states that 'The High Contracting Parties shall secure to everyone within their jurisdiction the rights and freedoms [enumerated in the Convention]'. Although the extraterritorial application of the ECHR is a controversial issue, the ECJ ruling in the Issa case is particularly enlightening:

[A] state may also be held accountable for violation of the Convention rights and freedom of persons who are in the territory of another state but who are found to be under the former state's authority and control ... Accountability in such situations stems from the fact that Article 1 of the Convention cannot be interpreted so as to allow a state party to perpetrate violations of the Convention on the territory of another state, which it could not perpetrate on its own territory. ${ }^{100}$ (emphasis added)

In addition, respect for HR is at the core of the European integration process as a general principle of law. The Charter of Fundamental Rights of the European Union recognises a number of rights to persons irrespective of nationality, such as the prohibition of torture and inhuman or degrading treatment or punishment (Article 4), the right to an effective

98 R Bermejo, 'Cuestiones en torno al estatuto jurídico de los detenidos en Guantánamo' in C Ramón (ed), Los retos humanitarios del siglo XXI (Tirant lo Blanch, Valencia, 2004) 62.

99 Geneva Convention (IV) relative to the Protection of Civilian Persons in Time of War. 12 August 1949 Part II.

100 Issa v Turkey (App no 31821/96) (2004) EHRR 567. 
remedy and to a fair trial (Article 47), the presumption of innocence and the right to defence (Article 48), and so forth. This is not a legally binding document but a useful source of interpretation for 'the courts of the Union and the Member States'. ${ }^{101}$

\section{d) Prosecution of arrested pirates, the bone of contention among Member States}

According to Article 2 JA, EU NAVFOR is entitled to 'arrest, detain and transfer' suspects in cases of piracy or armed robbery. It may also 'seize the vessels' and 'the goods on board' with a view to bringing them before a court. Article 12 JA deals with the prosecution of arrested suspects. It is stated that, provided Somalia accepts, pirates and confiscated goods will be transferred to 'the competent authorities of the flag Member State or of the third State participating in the operation, of the vessel which took them captive'.

The arrest of suspected pirates has been a source of substantial disagreement among MS. Most of them have not wanted to take full responsibility for their prosecution. In some cases, it is a matter of national legislation. In Spain, for instance, piracy is not typified by the Criminal Code. Therefore arrested pirates are not liable to appear before Spanish courts unless they are investigated under observance of the principle of universal justice, which allows serious crimes committed abroad to be prosecuted in Spain. In the Netherlands, there is an Anti-Piracy Act punishing such crimes with a 12-year sentence, but it had never been used until May 2009. In contrast, French national laws treat piracy, hostagetaking and armed robbery at sea as a crime and arrested pirates can face life imprisonment. Some MS (eg Denmark and Germany) can only prosecute pirates when they have attacked a national vessel or citizen.

This state of affairs justified the inclusion of a clause in Article 12 JA whereby if a State that has arrested pirates 'cannot, or does not wish to, exercise its jurisdiction,' detainees can be transferred to whichever State, whether it is a member or not, wishes to exercise its jurisdiction over them. International law, notably international humanitarian law remains the sole limit to this possibility, as stated in Article 12.2 JA, whose aim is to avoid suspected pirates being 'subjected to the death penalty, to torture or to any cruel, inhuman or degrading treatment.'

Following this provision, a Memorandum of Understanding (MoU) between the EU and Kenya was signed on 6 March $2009^{102}$ giving the

\footnotetext{
101 Charter of Fundamental Rights of the European Union [2007] OJ C303/2 Preamble.

102 Exchange of Letters between the European Union and the Government of Kenya on the conditions and modalities for the transfer of persons suspected of having committed acts of
} 
Kenyan authorities the right to prosecute under the abovementioned conditions. The MoU utterly hides EU obligations, ${ }^{103}$ focusing only on Kenyan commitments regarding detainees' fundamental rights. Article 2 (c) becomes a declaration of principles:

The signatories confirm that they will treat persons transferred under this [MoU], both prior to and following transfer, humanely and in accordance with international human rights obligations, including the prohibition against torture and cruel, inhumane and degrading treatment or punishment, the prohibition of arbitrary detention and in accordance with the requirement to have a fair trial.

The rights of transferred persons are further developed in Article 3. It is worth mentioning the right to be brought promptly before a judge who will decide on the lawfulness of detention (b); the right to a 'fair and public hearing by a competent, independent and impartial tribunal established by law' (d); the right to be presumed innocent (e); minimum guarantees regarding criminal charges (the right to be informed promptly in a language which the accused understands, the right to legal counsel, the right to trial without undue delay, and so forth) (f); the right to appeal against conviction and sentencing to a higher tribunal (though in accordance with the law of Kenya). Lastly, Article 4 establishes that '[n]o transferred person will be liable to suffer the death sentence. Kenya will, in accordance with the applicable laws, take steps to ensure that any death sentence is commuted to a sentence of imprisonment.' This provision is essential because Kenya has not yet abolished the death penalty.

Notwithstanding such commitments, prisons in Kenya are infamous for violence and human rights violations against inmates in conflict with the abovementioned provision. Therefore, it is the duty of European diplomatic authorities on the ground to effectively follow up on the conditions in which suspected pirates are held in Kenyan prisons, as well as the outcome of trials, to ensure that they meet the requirements laid down in Article 12.2 JA. Similarly, Article 5 (f) of the MoU enables access by international organisations to monitor prisoners' conditions. However, the enforcement of the provisions contained in the MoU remains limited since '... disputes concerning the interpretation or application of these provisions will be settled exclusively by diplomatic means between Kenya and EU representatives' (Article 8 (b)).

piracy and detained by the European Union-led naval force (EUNAVFOR), and seized property in the possession of EUNAVFOR, from EUNAVFOR to Kenya and for their treatment after such transfer [2009] OJ L79/49.

103 It has been suggested that Kenya would get speedboats, helicopters and modern fire trucks in exchange. M Gebauer and H Stark, 'Somali pirate trial tests limits of EU mission' Spiegel Online (1 April 2009) <http://www.spiegel.de/international/world/0,1518,616760,00. html>. 
The outcome of the first trial, which started in April 2009, is likely to jeopardise the authority of EU NAVFOR. It opposes Kenyan public prosecutors to nine suspected pirates, captured by a German frigate while escaping from the scene of a pirate attack. But there seem to be several flaws in the whole case. The pirates' German attorneys are trying to demonstrate that their arrest did not take place during the attack. In addition, the German captain threw the pirates' weapons overboard by mistake, which means that little evidence is left as proof of the detainees' actual activity.

The same applies to six Somali suspects who have been kept under arrest in Paris since April 2008. They are being prosecuted on charges of 'organised criminality' for hijacking a yacht and taking hostages with the intention of securing a ransom, a crime for which they face life imprisonment. Despite French defence lawyers' claims of irregularities regarding procedural rules (French soldiers were not entitled to carry out the arrests after the attack, irregular transfer to France, and custody conditions in violation of the European Convention on Human Rights) the Paris chamber in charge of preparing the case gave the green light for the trial on 6 April 2009.

Even though the risk of public exposure of military techniques might seem bad, there could not be a worse example of how to deal with arrested pirates than Spain, where the arrest and prosecution of pirates revealed contradictions between the military and the judiciary. The arrest of 14 suspected pirates by the Spanish frigate participating in Atalanta led to a blind alley in May 2009, when a judge of the Spanish Audiencia Nacional high court decided, upon the request of the public prosecutor, to claim jurisdiction over the pirates on several grounds (unlawful arrest, aggravated robbery and illegal bearing of weapons) separate from the international criminal jurisdiction which is expressly permitted by Article 105 UNCLOS. Their transfer to Kenya was blocked for several days and the validity of the Agreement EU-Kenya would have been brought into question in the event of the detainees being the subject of criminal proceedings started in Spain. Finally the judge backtracked and withdrew the motion, but the lack of co-ordination between the Spanish military and judiciary had already been publicly exposed.

EU NAVFOR has increasingly been capturing pirates and handing them over to Kenya ${ }^{104}$ but the abovementioned shortcomings still drive a number of participating MS to release captured pirates on the nearest beach once their ships and weapons have been confiscated. To paraphrase Waters, one of the overriding concerns for EU-led troops is the dif-

104 As of May 2009, EU NAVFOR forces had handed over 51 suspected pirates out of 52 of those arrested. EU NAVFOR, News in brief (14 May 2009) <http://www.consilium.europa. eu/showpage. aspx?id=1567\&lang=EN $>$. 
ficulty in anticipating the various domestic and international legal challenges which may arise. ${ }^{105}$ Such insecurity may eventually hinder the outcome of the mission.

\section{e) A modest financial and military commitment}

Financially speaking, EU NAVFOR is rather small, as the common costs are estimated at EUR $8.3 \mathrm{~m}$ for one year. This is in stark contrast with other ongoing military operations with a high-profile role for the EU in Africa, such as the peacekeeping force in eastern Chad (3,700 troops). Militarily speaking, no more than six European warships, as well as a few maritime surveillance aircraft and some 1,000 soldiers, are likely to be involved in the EU mission at any given time. Once again, the territorial scope bears no relation to the means employed. As Rear Admiral Philip Jones, Chief Commander of EU NAVFOR, once pointed out: the area is so large that hundreds of ships could exploit gaps in surveillance.

All in all, the actual commitment of MS towards EU NAVFOR seems modest compared to the demands. Efthimios Mitropoulos, Secretary General of the International Maritime Organisation, has expressed his wish 'to see governments committing sufficient numbers of warships, military aircraft and surveillance assets to the region and to co-ordinate their command and control under the auspices of a United Nations mandate' rather than one from a defence organisation. ${ }^{106}$

\section{A revision of the approach followed in Somalia in the light of EU foreign policy objectives}

Most scholars and politicians have called for a comprehensive approach to tackle piracy off Somalia. As Vines and Middleton have explained:

CFSP is about more than just military missions, and the EU is committed to building a comprehensive approach that combines traditional dimensions of security with support for economic development, good governance and institutional strengthening in countries at risk ... Although EU member states are less willing than in the past to commit troops to UN missions, the development of EU military operations acting as precursors to longer-term missions means EU soldiers will continue to play a direct role in creating peace and stability. ${ }^{107}$ (emphasis added)

105 C Waters, 'Is the Military Legally Encircled?' (2008) 8 Defence Studies 28.

106 Financial Times (3 November 2008).

107 A Vines and R Middleton, 'Options for the EU to Secure the African Peace and Security Architecture', Study requested by the European Parliament's Committee on Foreign Af- 
On the situation in Somalia, the UN Secretary-General Ban Ki-Moon stated clearly on 16 March 2009 that

[a]ny measures taken in both the short-term and the long-term to combat piracy and armed robbery off the coast of Somalia will require an integrated approach that incorporates support of the peace process; strengthening of capacity on land, such as support to AMISOM and the Somali security forces; strengthening of legal and maritime institutions such as the Somali and regional coastguards; addressing the lack of accountability by apprehending and prosecuting those suspected of acts of piracy and armed robbery at sea; strict compliance with arms embargoes in pursuance of the relevant Security Council resolutions; and peace-building efforts to empower local communities. ${ }^{108}$ (emphasis added)

Likewise, the General Affairs and External Relations Council (GAERC) affirmed on 26 May 2008

... its commitment to a comprehensive approach to a lasting settlement of the Somali crisis, covering its political, security and humanitarian aspects. It reiterates that the only way to restore the situation is through a political process ultimately inclusive of all concerned Somali stakeholders that renounce violence in the interest of the people of Somalia. ${ }^{109}$ (emphasis added)

Similar statements were included in the GAERC conclusions of 16 June, 22 July and 15 September 2008. The approach to the subject seemed to focus on the development and humanitarian aspects of the Somali conflict at that time from the perspective of an external observer. As the frequency of attacks against European ships increased throughout 2008, piracy was placed higher on the political agenda and the focus gradually shifted to security issues and concerns. From November 2008, the expression 'comprehensive approach' disappeared from Council conclusions and attention was paid solely to the fight against piracy and armed robbery off the Somali coast. ${ }^{110}$

fairs (February 2008) 35 <http://www.europarl.europa.eu/activities/committees/studies/ download.do?language $=e n \&$ file $=23448 \#$ search $=\% 20$ africa $\% 20$ peace $\% 20>$.

108 UNSC 'Report of the Secretary-General pursuant to Security Council Resolution 1846 (2008)' (2009) UN Doc S/2009/146 (16 March 2009) 10.

109 GAERC Conclusions 26-27 May 2008, Doc 9868/08 point 1. These conclusions made no reference to piracy before point 9 .

110 See GAERC Conclusions 10 November 2008, Doc. 15394/08; GAERC Conclusions 8 December 2008, Doc. 16862/08; GAERC Conclusions 26 February 2009, Doc. 6877/09; JHA Conclusions 26 February 2009, Doc. 6877/09; GAERC Conclusions 27 April 2009, Doc. 9098/09; GAERC Conclusions 26 February 2009, Doc. 6877/09. 
Meanwhile, individual EU politicians have continued calling for a comprehensive approach as the best solution for Somalia. The Commissioner for Fisheries and Maritime Affairs stated in January 2009: '[w]e firmly believe that the road to enhanced maritime security lies in an integrated approach. This should translate into effective and permanent civilian/military co-operation, coupled with cross-sectoral co-ordination at civilian level. ${ }^{111}$ Two months later, the Czech Presidency deemed it important that "the international response to piracy off the coasts of Somalia be accompanied by continued efforts and a longer-term strategy aiming to bring peace, stability and recovery to Somalia and its people'. ${ }^{112}$

Given the above, it would be no exaggeration to conclude that EU political leaders mention the need for an integrated approach to securing a long-lasting peace in the Horn of Africa more easily in speeches than in written documents resulting from negotiations. No Council document recalls in 2009 the link between the current situation off-shore and the need to address the impoverishment of the population on land. Interestingly enough, the Joint EU Africa Communiqué of 16 January 2009 neglects poverty as a root cause of piracy in favour of the power vacuum when stating that '... the issue of piracy is part of the continuing political crisis in Somalia, which should be dealt with for the achievement of a long-lasting sustainable resolution to the problem of piracy. ${ }^{113}$ As a result, long-term development tools become a secondary band-aid to an issue that is primarily perceived as a security concern.

Likewise, the Council conclusions of May 2009 attach more importance to the support of the security sector in Somalia prior to development, a line of reasoning reminiscent of the 'first security, then development' philosophy of the European Security Strategy of 2003:

The Council notes that a stable security environment in Somalia is vital for building state institutions, providing adequate humanitarian aid, kick-starting recovery efforts and reducing the threat of piracy. ... The Council supports the ambition of the new Transitional Federal Government to focus on the development and strengthening of national capacity in the security sector. The security sector should

\footnotetext{
111 Borg (n 46).

112 P Kaiser (Deputy Permanent Representative of the Czech Republic to the United Nations), Statement on behalf of the European Union on The Situation in Somalia at the Security Council Debate (New York 20 March 2009) <http://www.eu2009.cz/en/newsand-documents/statements-in-international-organisations/statement-on-behalf-of-theeuropean-union-on-the-situation-in-somalia-at-the-security-council-debate-on-march-20$-2009-13270 />$.

113 Council of the EU, Strategic Africa-EU Partnership: Joint Communique from the Ministerial Troika Meeting in Kleinmond, Doc. 5462/09 (16 January 2009) 7.
} 
be firmly committed to the rule of law, respect for human rights, and the principles of good governance and accountability. ${ }^{114}$

A final argument reinforcing change in the European approach towards Somalia and piracy is linked to the support provided by the EU to the signing on 29 January 2009 of a regional co-operation agreement between countries in the Gulf of Aden, known as the Djibouti Code of Conduct. ${ }^{115}$ This document aims to replicate in the Horn of Africa the excellent results of the regional agreement concluded in Asia that led to a significant decrease in pirate attacks in the Malacca Straits. This initiative was taken within the framework of the International Maritime Organization (IMO). Although the European Commission has the relevant competences within the framework of fisheries and maritime affairs, it did not participate in the Djibouti meeting because the EU as such is not a member of the IMO. Interestingly, EU representation was ensured, but not by the Presidency but by two UK Admirals of EU NAVFOR, reinforcing the perception of this initiative as a security issue rather than a maritime one.

Some reflections should be made as regards EU actors' tendency to praise the so-called global and integrated approach towards Somalia. As analysed in Section 2, this is not fully backed up by the facts. This conclusion has already been suggested regarding development aid but can also apply to Operation Atalanta.

When the UNSC adopted a Resolution that authorised resorting to force to deter and prevent pirate attacks and thus protect WFP vessels en route towards Somalia, the French Ambassador to the UN, Jean-Maurice Ripert, expressed his satisfaction stating that '.. at the end of the year, 3.5 million people will be depending only on the WFP and international

114 Council of the EU, GAERC Conclusions on External Relations, Doc 10009/09 (18-19 May 2009) 13.

115 The Djibouti Code of Conduct concerning the Repression of Piracy and Armed Robbery against Ships in the Western Indian Ocean and the Gulf of Aden was adopted by 17 countries at a high-level meeting held by the IMO in Djibouti. It immediately came into force with the signatures of nine regional States. The Code of Conduct starts by recognising the problem of piracy and armed robbery against ships, and its impact on the region. The signatories declare their intention to co-operate to the fullest extent, in a manner consistent with international law, in the repression of piracy and armed robbery against ships. The means of co-operation cover: first, sharing relevant information through a system of national focal points and information centres; second, interdicting ships suspected of engaging in acts of piracy or armed robbery against ships; third, ensuring that suspected pirates are apprehended and prosecuted; fourth, facilitating proper care, treatment, and repatriation for seafarers, fishermen, other shipboard personnel and passengers subject to acts of piracy or armed robbery against ships, particularly those who have been subjected to violence. The Code of Conduct also covers the possibilities of shared operations, such as nominating law enforcement or other authorised officials to embark on the patrol ships or aircraft of another signatory. <www.imo.org $>$. 
assistance ... pirates are killing Somalis every day, they are killing the Somali people, little by little. ${ }^{116}$ This statement offers just an example of the willingness to present individual and collective measures against Somali pirates before public opinion as if they were genuinely aimed at long-term objectives instead of short-term ones, and collective objectives instead of self-regarding ones. We will briefly explain these concepts next.

As explained in Section 2, in the post-Cold War international context, international actors increasingly feel the need to resort to structural foreign policy tools if they want to play a significant role on the international stage. The dimensions of foreign policy based on non-domination have proven their value since the nineties (eg Eastern enlargement of the European Union) whereas the limitations of a foreign policy purely based on domination have already been witnessed in other conflicts that seem to be at a dead end (eg Israel, Iraq, Afghanistan). In the context of the $21^{\text {st }}$ century, there is a growing need for structural policy tools which focus more on processes than conflicts, more on non-State actors and civil society than on elites and governmental actors, and more on longterm aspirations than short-term solutions to conflicts. Collective interests (those that benefit several States and actors) must be borne in mind besides self-regarding interests (those that benefit first and foremost the State in question) in a context of enhanced interdependence, and increasing vulnerability and uncertainty. ${ }^{117}$

As far as the European Union is concerned, recent years have witnessed a willingness to gradually complement its traditional role of 'civilian actor' in international politics with a more dominant one, slowly but surely taking steps towards a common defence policy. On the international stage, the ESDP helps the EU to assert its identity in front of traditional powers such as the US or Russia. However, the ESDP still plays a significant role at the internal level, since it makes it easier for many European States to maintain and foster their national defence policies in a context of increasing disdain towards defence budgets on the part of national public opinions. This might not be the case with the UK, but it certainly is when it comes to Spain or France. Presenting EU ESDP missions as seeking altruistic goals helps to win popular support at home as well as in target countries.

We can therefore conclude that external objectives (those aimed at having an actual impact on the situation in the partner country) are not always the trigger for foreign policy decisions. Public statements in the EU press showing a willingness to pursue external objectives can often

116 Stakeout de M Jean-Maurice Ripert à la suite du vote de la résolution 1838, 7 October 2008 <http://franceonu.org/spip.php?article2644>.

117 Keukeleire and MacNaughtan (n 24) 21-2. 
conceal other objectives related to the internal situation within the EU. Three hidden objectives must however be taken into account: integration objectives, identity objectives and interrelational objectives. ${ }^{118}$ Certain indicators show that this conclusion can be seen in the European response towards Somalia.

After an overall appraisal of EU initiatives aimed at tackling the situation in Somalia, the least that one can say is that European action is a drop in the ocean, insufficient to address the root causes of the conflict. On land, the effectiveness of EC development co-operation is hampered by the high risk situation in which aid must be delivered. The granting of further amounts of funds is thus discouraged and diverted towards securer countries. Off-shore, EU NAVFOR-Atalanta has not been given the means to effectively carry out its mission to the end. It can therefore be suggested that European action towards Somalia is not primarily driven by external objectives, despite the public statements of European spokespersons. If it was, more conventional and non-conventional means would have been committed to achieving stability on shore in order to end piracy off the Somali coast. Consequently, the abovementioned internal objectives are somehow hidden behind the facade of European altruism.

Internal objectives refer to the European Union itself and tend to strengthen integration and European identity. The simple fact of launching a naval military mission was itself a milestone in ESDP history. It proved once again that there was agreement among MS on defence matters and involved navies for the first time ever, thus supporting those advocating further steps in the field of capabilities. The images of EU NAVFOR frigates escorting WPF vessels, as well as those of successful skirmishes with pirates, have been shown around the world through official websites and newspapers. Subsequently, EU visibility as a global actor has been enhanced, particularly for internal consumption.

Other internal objectives refer to EU foreign policy as a bottom-up Europeanisation of national foreign policies. France and Spain were the launchers of the European initiative in Somalia. However, a closer look might show that French and Spanish interest in the successful accomplishment of EU NAVFOR's mission has much more of a national than a European nature.

The launch of the mission was on 8 December 2008. France held the EU Presidency until the end of that year and one of the main goals of the French Presidency was to foster European defence collaboration with a view to being fully reintegrated into the NATO military structure after an absence of 43 years, a decision announced at the Strasbourg and Kehl

118 Keukeleire and MacNaughtan (n 24) 12-13. 
NATO summit (3-4 April 2009). French President Sarkozy linked this decision to progress in the ESDP during the second semester of 2008. Therefore, French diplomacy tried to take modest though realistic steps towards achieving European collaboration in defence matters. Hence the symbolic importance attached to the war on pirates. ${ }^{119}$

The Spanish boost to Atalanta was also driven by self-regarding objectives to a great extent. Spanish fishermen depend largely upon catches in the Indian Ocean. After several serious attempts, the Playa de Bakio vessel was hijacked by pirates in April 2008. Its release came after the ship's owner paid a ransom. The inactivity of Prime Minister Zapatero's government was then exposed in Parliament by the Basque nationalist party ${ }^{120}$ (most fishing or seafaring companies in the Indian Ocean are Basque). At the time, this party played an important role as a necessary partner for President Zapatero in the daily implementation of policy. As a result, a government whose lack of affection for defence matters is wellknown across Europe (sudden withdrawals from both Iraq and Kosovo are good examples of this), unsurprisingly waved the flag of European defence when it came to the Gulf of Aden. However, a critical and mostly unexpected shift in local politics happened in March 2009, when electoral results opened the door for the first non-nationalist Basque government ever, headed by a Socialist. Consequently, the initial position of the Spanish government has changed substantially.

To sum up, the evolution of events in the Indian Ocean, and particularly in Somalia, reflects in our opinion a failure of the 'first security, then development' philosophy of the 2003 European Security Strategy ${ }^{121}$ and is a flawed attempt at making the EU evolve from a 'civilian only' security actor resorting solely to 'soft power' means, towards a 'hard power' that can effectively use its military power. ${ }^{122}$

That EU NAVFOR has been granted insufficient means is a fact. However, the question remains unanswered as to whether the underlying reason for this is continuously dropping defence budgets, the military capability gap or, more likely, the absence of a clear MS commitment

119 James Blitz, 'French optimism on plan for EU defence pool', Financial Times (2 October 2008); Laurent Zecchini, 'Face aux attaques de pirates, la mobilisation navale internationale montre ses limites', Le Monde (Paris 19 November 2008).

120 Parliamentary debate in the Spanish Congreso de los Diputados, 22 May $2008<\mathrm{http}: / /$ www.congreso.es/portal/page/portal/Congreso/PopUpCGI?CMD=VERLST\&BASE=puw9 $\&$ FMT $=$ PUWTXDTS.fmt $\& D O C S=1-1 \&$ QUERY $=\% 28 C D C 200805220027$. CODI. $\% 29 \#(\mathrm{P} \%$ C3 $\%$ Algina31)>.

121 European Security Strategy, Brussels, 12 December 2003 < http://ue.eu.int/uedocs/ cmsUpload/78367.pdf>.

122 S Silvestri, 'Revising the European Security Strategy: arguments for discussion' (2008) Instituto Affari Internazionale, <http://www.iai.it/pdf/IAI_Silvestri_300508.pdf> 7. 
towards finding a structural and enduring solution for Somalia. In fact, security of oil and goods supply in Europe appears to be the main goal, as no major solution had been fostered by EU partners at the UNSC level until piracy put supplies at risk.

Two other areas have been proposed in which the commitment of the EU and MS towards Somalia could be demonstrated, but neither have prospered. Firstly, the African Union has repeatedly called on the EU to deploy a peacekeeping force in Somalia, but the EU has always rejected a commitment on land. Secondly, allegations concerning European companies dumping toxic waste off the Somali coast have never received a definite answer from EU governments.

At present, it seems to us risky to openly assert the success of EU NAVFOR Operation Atalanta when only six months have passed since it was launched. The renewal of its mandate by the Council notwithstanding, every day it becomes more likely that this operation will fall short of its ambitions. ${ }^{123}$ However, nobody dares to picture a scenario in which the first European naval military mission would return home empty-handed or the impact which that contingency could have not only on the ESDP, but also on the external perception of the EU as a 'global actor'.

123 On the recommendation of SG/HR Javier Solana ('Edited remarks at the meetings of EU defence ministers in the framework of the GAERC Council' Doc S128/09 (18 May 2009) 3), the Council decided on 15 June 2009 to extend the mandate of Operation Atalanta for one year from its current end date of 13 December 2009. 